\title{
Using highly time-resolved online mass spectrometry to examine biogenic and anthropogenic contributions to organic aerosol in Beijing $\dagger$
}

\author{
Archit Mehra, (D) a Manjula Canagaratna, ${ }^{b}$ Thomas J. Bannan, (D) a \\ Stephen D. Worrall, iD ${ }^{c}$ Asan Bacak, ${ }^{d}$ Michael Priestley, ${ }^{e}$ Dantong Liu, ${ }^{f}$ \\ Jian Zhao, ${ }^{9}$ Weiqi $\mathrm{Xu},{ }^{9}$ Yele Sun, (D) 9 Jacqueline F. Hamilton, ${ }^{\text {h }}$ \\ Freya A. Squires, iD h James Lee, (D) ${ }^{\mathrm{h}}$ Daniel J. Bryant, ${ }^{\mathrm{h}}$ \\ James R. Hopkins, ${ }^{\text {h }}$ Atallah Elzein, ${ }^{\text {h }}$ Sri Hapsari Budisulistiorini, (D) ${ }^{\text {h }}$ \\ Xi Cheng, i Qi Chen, 'Y Yuwei Wang, 'jin Wang, iD j Harald Stark, ${ }^{\text {bkl }}$ \\ Jordan E. Krechmer, (D b James Brean, ${ }^{\mathrm{m}}$ Eloise Slater, ${ }^{\mathrm{n}}$ Lisa Whalley, ${ }^{\text {no }}$ \\ Dwayne Heard, (iD ${ }^{n}$ Bin Ouyang, ${ }^{p}$ W. Joe F. Acton, ${ }^{p}$ \\ C. Nicholas Hewitt, (D) ${ }^{p}$ Xinming Wang, (D) a Pingqing Fu, (D) $r$ \\ John Jayne, ${ }^{b}$ Douglas Worsnop, ${ }^{\text {b James Allan, }}$ as Carl Percival (iD $\ddagger^{a}$ \\ and Hugh Coe*aj
}

Received 27th June 2020, Accepted 23rd September 2020

DOI: $10.1039 /$ dOfd00080a

Organic aerosols, a major constituent of fine particulate mass in megacities, can be directly emitted or formed from secondary processing of biogenic and anthropogenic volatile organic compound emissions. The complexity of volatile organic compound emission sources, speciation and oxidation pathways leads to uncertainties in the key sources and chemistry leading to formation of organic aerosol in urban areas. Historically, online measurements of organic aerosol composition have been unable to resolve specific markers of volatile organic compound oxidation, while offline analysis of markers focus on a small proportion of organic aerosol and lack the time resolution to carry out detailed statistical analysis required to study the dynamic changes in aerosol sources and chemistry. Here we use data collected as part of the joint UKChina Air Pollution and Human Health (APHH-Beijing) collaboration during a field campaign in urban Beijing in the summer of 2017 alongside laboratory measurements of secondary organic aerosol from oxidation of key aromatic precursors (1,3,5-trimethyl benzene, 1,2,4-trimethyl benzene, propyl benzene, isopropyl benzene and 1-methyl naphthalene) to study the anthropogenic and biogenic contributions to organic aerosol. For the first time in Beijing, this study applies positive matrix factorisation to online measurements of organic aerosol composition from a time-of-flight iodide chemical ionisation mass spectrometer fitted with a filter inlet for gases and aerosols (FIGAEROToF-I-CIMS). This approach identifies the real-time variations in sources and oxidation processes influencing aerosol composition at a near-molecular level. We identify eight 
factors with distinct temporal variability, highlighting episodic differences in $O A$ composition attributed to regional influences and in situ formation. These have average carbon numbers ranging from $\mathrm{C}_{5}-\mathrm{C}_{9}$ and can be associated with oxidation of anthropogenic aromatic hydrocarbons alongside biogenic emissions of isoprene, $\alpha-$ pinene and sesquiterpenes.

\section{Introduction}

Organic aerosols (OA) are a major constituent of fine particulate mass (PM) ${ }^{2}$ which impact upon climate, air quality and human health. ${ }^{3-5}$ Primary OA (POA) are directly emitted from natural and anthropogenic biomass burning alongside fossil fuel combustion, while secondary OA (SOA) are formed from the atmospheric oxidation of volatile organic compounds (VOC) emitted from both biogenic and anthropogenic sources. ${ }^{6}$ The relative contributions of biogenic and anthropogenic sources to OA remain poorly constrained owing to their diverse speciation $^{7-9}$ and complex oxidation pathways. ${ }^{6,10,11}$

Beijing is a megacity which continues to suffer from severe air pollution events despite recent reductions in primary emission of $\mathrm{PM}^{\mathbf{1 2 - 1 4}}$ and nitrogen oxides $\left(\mathrm{NO}_{x}\right) .{ }^{15}$ These have been associated with high emissions of VOC from diverse

${ }^{a}$ Centre for Atmospheric Science, School of Earth and Environmental Sciences, The University of Manchester, Manchester, M13 9PL, UK. E-mail: hugh.coe@manchester.ac.uk

${ }^{b}$ Center for Aerosol and Cloud Chemistry, Aerodyne Research Inc, Billerica, Massachusetts, USA

${ }^{c}$ Aston Institute of Materials Research, School of Engineering and Applied Science, Aston University, Birmingham, B4 7ET, UK

${ }^{d}$ Turkish Accelerator \& Radiation Laboratory, Ankara University Institute of Accelerator Technologies, Gölbaşı Campus, 06830 Golbasi, Ankara, Turkey

${ }^{e}$ Department of Chemistry and Molecular Biology, University of Gothenburg, Gothenburg, Sweden

${ }^{f}$ Department of Atmospheric Sciences, School of Earth Sciences, Zhejiang University, Hangzhou, Zhejiang, China

${ }^{g}$ State Key Laboratory of Atmospheric Boundary Physics and Atmospheric Chemistry, Institute of Atmospheric Physics, Chinese Academy of Sciences, Beijing 100029, China

${ }^{h}$ Wolfson Atmospheric Chemistry Laboratories, Department of Chemistry, University of York, UK

iState Key Joint Laboratory of Environmental Simulation and Pollution Control, College of Environmental Science and Engineering, Peking University, Beijing, China

${ }^{j}$ Shanghai Key Laboratory of Atmospheric Particle Pollution and Prevention (LAP3), Department of Environmental Science \& Engineering, Fudan University, Jiangwan Campus, Shanghai 200438, China

${ }^{k}$ Cooperative Institute for Research in Environmental Sciences (CIRES), University of Colorado, Boulder, CO 80309, USA

${ }^{l}$ Department of Chemistry, University of Colorado, Boulder, CO 80309, USA

${ }^{m}$ Division of Environmental Health and Risk Management, School of Geography, Earth and Environmental Sciences, University of Birmingham, Edgbaston, Birmingham B15 2TT, UK

${ }^{n}$ School of Chemistry, University of Leeds, Leeds, LS2 9JT, UK

${ }^{\circ}$ National Centre for Atmospheric Science, University of Leeds, Leeds, LS2 9JT, UK

${ }^{p}$ Lancaster Environment Centre, Lancaster University, Lancaster, LA1 4YQ, UK

${ }^{q}$ Guangzhou Institute of Geochemistry, Guangzhou, China

${ }^{r}$ Institute of Surface-Earth System Science, Tianjin University, Tianjin, China

${ }^{s}$ National Centre for Atmospheric Science, University of Manchester, Manchester, UK

$\dagger$ Electronic supplementary information (ESI) available. See DOI: 10.1039/dofd00080a

\$ Current address: NASA Jet Propulsion Laboratory, California Institute of Technology, Pasadena, CA, USA. 
sources $^{\mathbf{1 6 , 1 7}}$ which lead to enhanced ozone production ${ }^{\mathbf{1 8 , 1 9}}$ and SOA formation ${ }^{20}$ alongside regional transport which is an important source of semi-volatile organic compounds (SVOC), intermediate-volatility organic compounds (IVOC), POA and SOA in Beijing during the summertime..$^{21,22}$

Historically, source apportionment of OA has been limited to low timeresolution high molecular precision offline measurements of molecular tracers, focusing on the behaviour of specific VOC systems including isoprene, ${ }^{23-26} \alpha-$ pinene $^{27}$ and toluene. ${ }^{28,29}$ More recently, highly time-resolved bulk composition measurements by aerosol mass spectrometry (AMS) and aerosol chemical speciation monitors (ACSM) have been used to apportion OA to broad source classifications including fossil fuels (FFOA), biomass burning (BBOA) and oxidised organic aerosol (OOA). ${ }^{\mathbf{1 8 , 2 1 , 3 0 , 3 1}}$ These techniques alone are thus limited in their capability to constrain the dynamic sources and processes governing OA transformation at a molecular level. SOA typically contributes $52-64 \%$ of OA in Beijing, ${ }^{21}$ yet despite its diverse biogenic and anthropogenic sources, is classified solely on the basis of its bulk degree of oxidation into less-oxidised OOA (LO-OOA) and more-oxidised OOA (MO-OOA). ${ }^{31,32}$

Recently, highly-time resolved online chemical ionisation mass spectrometry (CIMS) techniques have been applied to in situ measurements of trace gas ${ }^{33-36}$ and aerosol composition ${ }^{37,38}$ providing sensitive and selective detection of molecules spanning an atmospherically relevant oxidation range. ${ }^{39-41}$ These have been employed for the study of VOC oxidation, driving novel insights into gas-phase and SOA chemistry, ${ }^{\mathbf{1 4 2}-46}$ including detailed studies of highly oxygenated organic molecules (HOM), ${ }^{42,47,48}$ oligomers ${ }^{49}$ and new particle formation (NPF). ${ }^{50,51}$ Their application in ambient measurements have mostly focused on gas phase oxidised organic compounds, ${ }^{52-54}$ with fewer studies measuring OA composition directly. ${ }^{55,56}$

This study uses a Filter Inlet for Gases and Aerosols (FIGAERO) ${ }^{57}$ coupled to an online CIMS interface using an iodide reagent ion scheme for near-molecular identification of $\mathrm{OA}$ composition. ${ }^{58}$ This technique has been successfully applied in Beijing previously to study a small subset of OA components, ${ }^{59}$ while here we focus on characterising its bulk composition and sources. We couple laboratory measurements of SOA from oxidation of aromatic hydrocarbons ${ }^{1}$ with ambient measurements from summer 2017 and apply positive matrix factorisation (PMF) $)^{52,60-62}$ to integrated thermal desorption profiles from FIGAERO-I-CIMS for the first time in Beijing to identify anthropogenic and biogenic contributions to $\mathrm{OA}$.

We make use of the abundance of chemical information, evaluated in terms of its uncertainty and carry out a single factor analysis for the whole dataset to show that the behaviour of ions can be broken down into distinct sub-groups. The different time periods are used to interpret the results of the single PMF analysis, both diurnally and across three time periods defined according to meteorological and chemical conditions. In order to evaluate these groups, we identify marker ions which can be related to previous work in the lab and field, where those ions are discrete and linked to particular sources and pathways. We identify these marker ions by correlation and use them throughout the paper to understand the sources.

Ions are selected for PMF using the approach outlined in ESI†. The temporal trends and bulk properties of the PMF factors are discussed in Section 3.1, 
following which the aromatic content is evaluated in Section 3.2 and the key marker ions are identified in Section 3.3. These together are used in the interpretation of the factors in Section 3.4. In Section 4, we compare the derived factors with air mass origins, and external markers.

\section{Methodology}

Measurements were carried out as part of the joint UK-China Air Pollution and Human Health (APHH) project, which involved an intensive summer measurement campaign during May-June 2017. ${ }^{63}$ The measurement site was located at the Institute of Atmospheric Physics, Chinese Academy of Sciences (IAP-CAS) in Beijing $\left(39^{\circ} 58^{\prime} 28^{\prime \prime} \mathrm{N}, 116^{\circ} 22^{\prime} 16^{\prime \prime} \mathrm{E}\right)$, an urban site in the north of Beijing, between the third and fourth ring roads. The analysis in this paper will focus on a period near to the end of the summer measurement campaign from $2^{\text {nd }}-18^{\text {th }}$ June 2017 , which was chosen owing to stable instrument parameters during this time period. Positive matrix factorisation (PMF) analysis was carried out on measurements from a time-of-flight chemical ionisation mass spectrometer (ToF-CIMS) using an iodide ionisation system ${ }^{58}$ coupled to a FIGAERO. This paper focuses on the results from the FIGAERO-CIMS, with other co-located measurements utilised to frame the discussion and for interpretation of factors. A detailed description of the methodology is provided in the ESI. $\dagger$

\section{Results}

\subsection{Overview of FIGAERO-CIMS factor solution}

FIGAERO-CIMS measurements during the period of $2^{\text {nd }}-18^{\text {th }}$ June 2017 are presented in this study alongside comparisons with various co-located measurements as part of the APHH-Beijing field campaign. ${ }^{63}$ Here, we briefly highlight the key features of relevance for description of the derived PMF factors oxidants $(\mathrm{OH}$, $\mathrm{O}_{3}$ and $\mathrm{NO}_{3}$ ), ambient temperature and aerosol mass concentrations as measured by AMS.

The measurements presented in this study have been split into three periods: period 1 (2017-06-02 13:00 to 2017-06-07 10:00), period 2 (2017-06-08 04:00 to 2017-06-13 18:00) and period 3 (2017-06-13 20:00 to 2017-06-18 10:00) based on differing meteorological and oxidant conditions. Specifically, the criteria used to separate these three periods were the relative differences in ambient temperature, $\mathrm{NO}_{x}, \mathrm{OH}$ and $\mathrm{O}_{3}$ mixing ratios.

Period 1 is characterised by lower- $\mathrm{NO}_{x}$ conditions ( $26 \mathrm{ppb}$ ), lower temperatures $\left(23{ }^{\circ} \mathrm{C}\right)$ and average ozone concentrations ( $\left.42 \mathrm{ppb}\right)$ alongside a $41 \%$ contribution of organics to total aerosol mass (Fig. S5†). In contrast, period 2 has elevated $\mathrm{NO}_{x}$ concentrations (39 ppb) and low particle mass loadings $\left(8 \mu \mathrm{g} \mathrm{m}^{-3}\right)$, which were dominated by organics, making up $54 \%$ of aerosol mass (Fig. S5 $\dagger$ ). Period 3 is distinguished most by its high $\mathrm{O}_{3}$ (71 ppb, mean daytime 07:00-19:00 - $93 \mathrm{ppb}$ ), high overnight $\mathrm{NO}_{3}(16 \mathrm{ppt})$ and high ambient temperature $\left(31^{\circ} \mathrm{C}\right)$. In addition, period 3 showed high sulphate and organic contributions to aerosol mass, contributing $26 \%$ and 54\%, respectively (Fig. S5 $\dagger$ ). It should be noted that at peak photochemistry, $\mathrm{OH}$ concentrations can peak at concentrations reaching as high as $2.8 \times 10^{7}$ molecules $\mathrm{cm}^{-3}$, over an order of magnitude higher than the global mean average concentration ${ }^{64}$ of $1.5 \times 10^{6}$ molecules $\mathrm{cm}^{-3}$. 
Eight FIGAERO-CIMS organic aerosol factors were resolved during this study (Fig. 1 and 2). Here, we briefly introduce these factors, their bulk composition, temporal behaviour and trends across the measurement period. The bulk composition of each factor is shown in Table 1, and includes average formula and molecular weight alongside elemental ratios of oxygen-to-carbon $(\mathrm{O}: \mathrm{C})$, hydrogen-to-carbon $(\mathrm{H}: \mathrm{C})$ and nitrogen-to-carbon $(\mathrm{N}: \mathrm{C})$ which are used to calculate the carbon oxidation state (OSc) of each factor: ${ }^{65}$

$$
\mathrm{OSc}=(2 \times \mathrm{O}: \mathrm{C})-\mathrm{H}: \mathrm{C}-(5 \times \mathrm{N}: \mathrm{C})
$$

This metric is widely used for comparison of oxidised components of organic aerosol. It makes the assumption that all the nitrogen atoms exist as nitrate

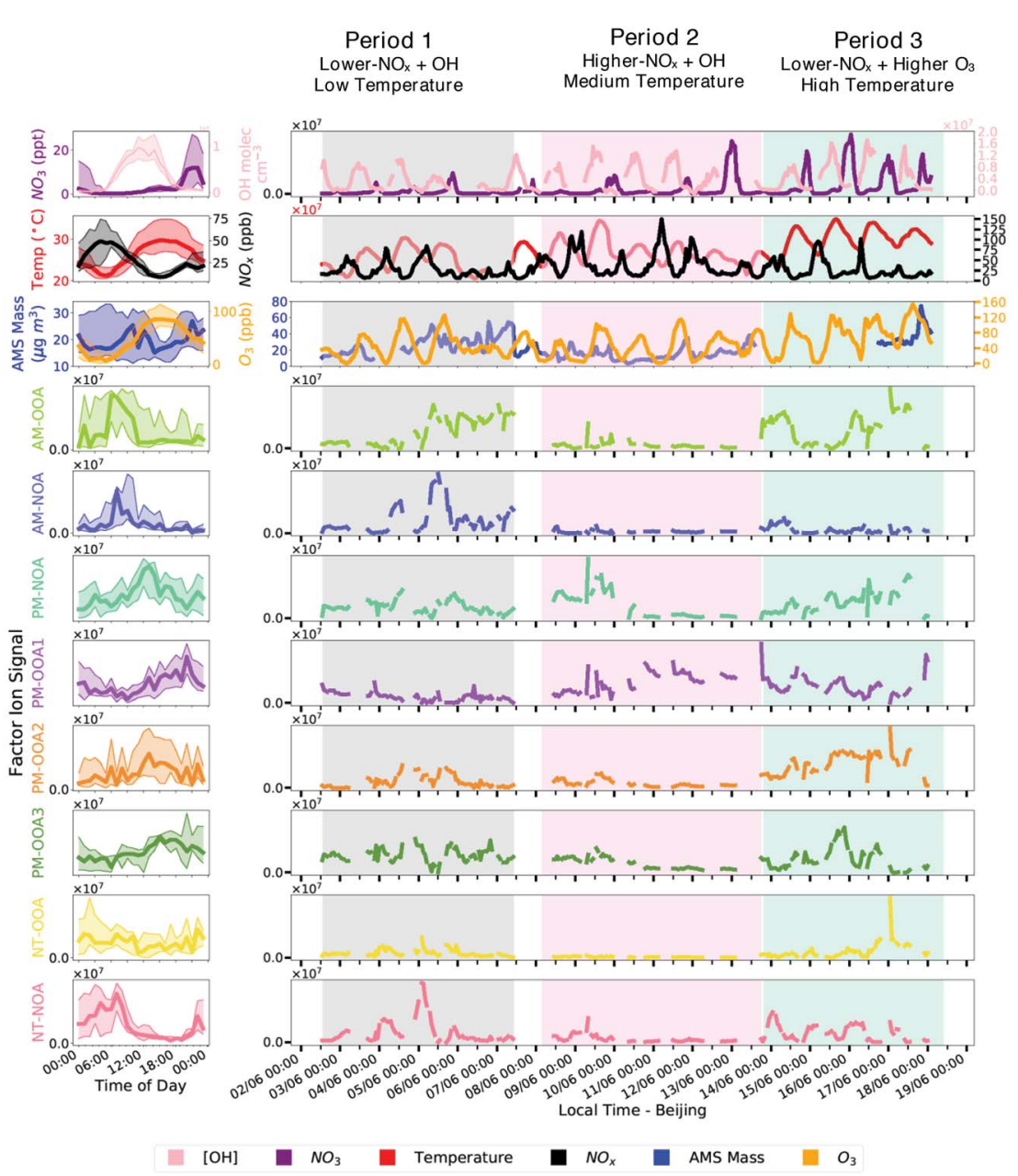

Fig. 1 Diurnal trends (left) and time series (right) of PMF factors, AMS mass, temperature, $\mathrm{O}_{3}, \mathrm{NO}_{x}, \mathrm{NO}_{3}$ and $\mathrm{OH}$. The PMF factors are ordered and named with a prefix according to diurnal trend that peak in the morning (AM), afternoon (PM), and night (NT). 

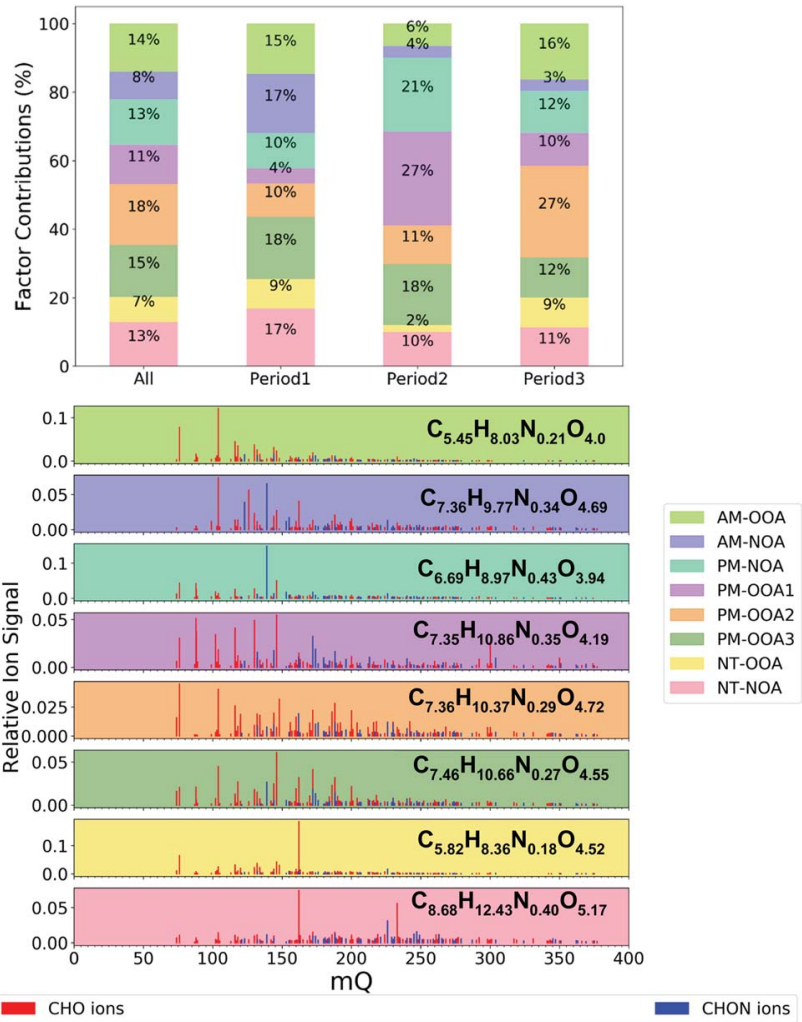

Fig. 2 Contributions of factors to total observed signal during different time periods (top) and factor mass spectra (bottom) where $m_{Q}$ is the mass of the ions and the ion formulas shown are the signal weighted average ion formulas of each factor.

groups and there may be associated uncertainties for nitro groups or amines and amides. ${ }^{65}$ Additionally, the contribution to factor mass spectra from ions containing carbon, hydrogen and oxygen only ( $\mathrm{CHO}$ ) and carbon, hydrogen, oxygen and nitrogen only (CHON) is included as well as the contribution of highly oxygenated organic molecules (HOM), defined here as ions which contain six or more oxygen atoms. ${ }^{48}$

The factors are distinguished by their diurnal profiles, splitting into two morning factors (AM), four afternoon factors (PM) and two night-time factors (NT). All factors have some nitrogen content, but to distinguish between them here we name those with higher nitrogen content (CHON\% - Table 1) as NOA. The morning factors consist of nitrogen-containing organic aerosol (AM-NOA) and oxidised organic aerosol (AM-OOA). Of the afternoon factors, two are dominant diurnally during the higher- $\mathrm{NO}_{x}$ conditions, and particularly abundant during period 2 (Fig. 2), one which is nitrogen-containing (PM-NOA) and one which is oxidised organic aerosol (PM-OOA2 and PM-OOA3). The remaining two afternoon factors show similar composition and are diurnally most prevalent during the lower- $\mathrm{NO}_{x}$ afternoon hours (PM-OOA1 and PM-OOA2). The night-time factors consist of nitrogen-containing organic aerosol (NT-NOA) and oxidised organic aerosol (NT-OOA). 
Table 1 Bulk composition of PMF factors

\begin{tabular}{|c|c|c|c|c|c|c|c|c|c|}
\hline \multirow[b]{2}{*}{ Factor } & \multicolumn{6}{|c|}{ Signal weighted bulk properties } & \multirow{2}{*}{$\begin{array}{l}\text { CHO } \\
(\%)\end{array}$} & \multirow{2}{*}{$\begin{array}{l}\text { CHON } \\
(\%)\end{array}$} & \multirow{2}{*}{$\begin{array}{l}\text { HOM } \\
(\%)\end{array}$} \\
\hline & $\mathrm{O}: \mathrm{C}$ & $\mathrm{H}: \mathrm{C}$ & $\mathrm{N}: \mathrm{C}$ & OSc & Average formula & MW & & & \\
\hline $\begin{array}{l}\text { AM- } \\
\text { NOA }\end{array}$ & 0.78 & 1.34 & 0.059 & -0.081 & $\mathrm{C}_{7.36} \mathrm{H}_{9.77} \mathrm{~N}_{0.34} \mathrm{O}_{4.69}$ & 177.96 & 71 & 29 & 23 \\
\hline $\begin{array}{l}\text { AM- } \\
\text { OOA }\end{array}$ & 0.89 & 1.51 & 0.038 & 0.092 & $\mathrm{C}_{5.45} \mathrm{H}_{8.03} \mathrm{~N}_{0.21} \mathrm{O}_{4.0}$ & 140.58 & 84 & 16 & 10 \\
\hline $\begin{array}{l}\text { PM- } \\
\text { NOA }\end{array}$ & 0.69 & 1.36 & 0.064 & -0.308 & $\mathrm{C}_{6.69} \mathrm{H}_{8.97} \mathrm{~N}_{0.43} \mathrm{O}_{3.94}$ & 158.38 & 64 & 36 & 16 \\
\hline $\begin{array}{l}\text { PM- } \\
\text { OOA3 }\end{array}$ & 0.72 & 1.43 & 0.034 & -0.162 & $\mathrm{C}_{7.46} \mathrm{H}_{10.66} \mathrm{~N}_{0.27} \mathrm{O}_{4.55}$ & 176.92 & 79 & 21 & 20 \\
\hline $\begin{array}{l}\text { PM- } \\
\text { OOA1 }\end{array}$ & 0.69 & 1.53 & 0.051 & -0.402 & $\mathrm{C}_{7.35} \mathrm{H}_{10.86} \mathrm{~N}_{0.35} \mathrm{O}_{4.19}$ & 171.16 & 74 & 26 & 21 \\
\hline $\begin{array}{l}\text { PM- } \\
\text { OOA2 }\end{array}$ & 0.79 & 1.42 & 0.042 & -0.051 & $\mathrm{C}_{7.36} \mathrm{H}_{10.37} \mathrm{~N}_{0.29} \mathrm{O}_{4.72}$ & 178.48 & 78 & 22 & 27 \\
\hline $\begin{array}{l}\text { NT- } \\
\text { NOA }\end{array}$ & 0.68 & 1.46 & 0.051 & -0.355 & $\mathrm{C}_{8.68} \mathrm{H}_{12.43} \mathrm{~N}_{0.40} \mathrm{O}_{5.17}$ & 205.14 & 68 & 32 & 38 \\
\hline $\begin{array}{l}\text { NT- } \\
\text { OOA }\end{array}$ & 0.89 & 1.48 & 0.028 & 0.156 & $\mathrm{C}_{5.82} \mathrm{H}_{8.36} \mathrm{~N}_{0.18} \mathrm{O}_{4.52}$ & 153.06 & 87 & 13 & 14 \\
\hline
\end{tabular}

\subsection{Comparison with aromatic SOA}

VOC contributions to SOA are often estimated through application of yields derived from laboratory studies ${ }^{66-68}$ to ambient VOC concentrations. ${ }^{19,69}$ It has been suggested by such approaches that aromatic VOCs, abundant in Beijing during the summertime ${ }^{70}$ are the dominant contributor to SOA,$^{71}$ with contributions as high as $98.2 \%{ }^{19}$ The importance of aromatic VOCs was further highlighted during the Asia Pacific Economic Conference (APEC) emission controls, where a $50-80 \%$ reduction in aromatic VOCs from vehicle emissions and solvent evaporation ${ }^{72}$ was concurrent with a $37 \%$ reduction in SOA formation. ${ }^{73}$ However, these measurement approaches are indirect and thus limited by large variations in SOA yields, ${ }^{74}$ effects of VOC mixtures upon SOA chemistry $^{10,75,76}$ and meteorology. ${ }^{77}$

Recently, we studied the composition of SOA from several aromatic hydrocarbons using a FIGAERO-CIMS and identified a suite of ring-retaining products, including HOM, which contributed up to $43 \%$ of observed signal from single component aromatic experiments. ${ }^{1}$ Here we compare the ions observed in the ambient factors with those from this aromatic study to estimate the potential contribution that aromatics could have to measured SOA in Beijing. As discussed in Mehra et al. (2020), ${ }^{1}$ many ions observed from aromatics have ion formulas concurrent with products from oxidation of other precursors. Due to the potential for ring-scission products, in particular, to be attributed to many different sources, here we focus upon the ring-retaining products identified from aromatic oxidation in Mehra et al. (2020). ${ }^{1}$ Using these ions as markers provides a lower constraint on the contribution of aromatic SOA to the observed factor mass spectra, as many of the small oxidised products in the factors are likely to have an aromatic contribution from ring-scission. 


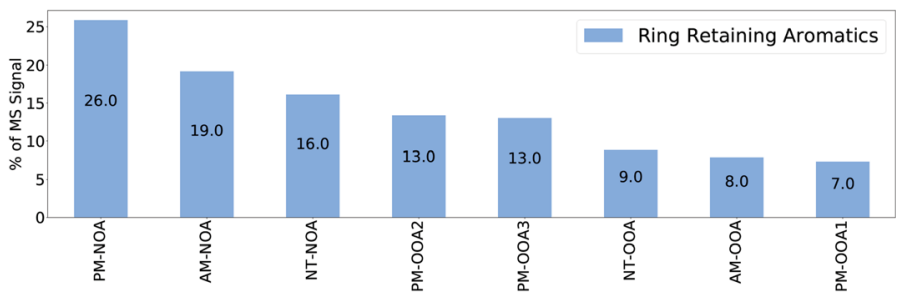

Fig. 3 Contribution of ring-retaining aromatic SOA ions from Mehra et al. $(2020)^{1}$ to PMF factor mass spectra.

Fig. 3 shows the proportion of mass spectral signal of each factor attributable to ion formulae measured during the aromatic oxidation experiments classified as ring-retaining $\left(\mathrm{C}_{6}-\mathrm{C}_{9}\right.$ and double bound equivalent $\left.(\mathrm{DBE}) \geq 4\right) .{ }^{1}$ This analysis indicates that the PM-NOA has the largest potential contribution from aromatic SOA products (26\%), followed by AM-NOA (19\%) and NT-NOA (16\%). It should be noted that these contributions do not include nitro-aromatics which were not observed by Mehra et al. $(2020)^{1}$ due to the lower $\mathrm{HO}_{2}$ : NO ratios employed in these experiments. Though there is ambiguity in the potential sources of some specific ions, this comparison provides a useful basis for comparing SOA in different factors.

\subsection{Identification of marker ions for factors}

Many of the most abundant ions observed across the factor mass spectra (Fig. S5S8 $\dagger$ ) are small oxidised ions which can be attributed to various sources including ring-scission pathways from aromatic oxidation ${ }^{\mathbf{1}}$ and fragmentation pathways of biogenic oxidation. ${ }^{78}$ These ions are less likely to act as markers of a particular source and thus here we outline an approach taken to identify marker ions for the factors.

We calculated the Pearson correlation coefficient $(R)$ between the time series of each ion and the factors themselves, and those which have an $R$ of greater than 0.5 are considered potential marker ions of the factor. These ions are ranked by decreasing correlation and the top twenty ions, where available, are classified as markers of a given factor. This threshold enables more ions to be included in this classification, as use of single ions as markers can lead to misinterpretation of factor profiles due to potential isomers from different sources. ${ }^{1}$ A similar approach has been applied previously with PMF analysis, whereby a cluster analysis of the ions and factors yielded unique or nearly unique markers for each factor. $^{79}$

Marker ions span a broad range of chemical space, as shown in Fig. 4, and with the exception of AM-OOA and NT-OOA, which show similar composition, are more unique than the small oxidised ions abundant in the factor mass spectra (Fig. S5-S8 $\dagger$ ). Marker ions contribute differently to the mass spectra of the factors, with the highest contribution to the mass spectra from marker ions observed for NT-NOA (79\%) followed by AM-OOA (61\%), AM-NOA (57\%), PM-OOA3 (53\%), PMOOA2 (25\%) and PM-NOA (21\%). In the case of PM-OOA1, no ions show a strong correlation with the time series of this factor, in some cases this can suggest factor splitting in the PMF solution. ${ }^{62}$ In order to establish if this was the case, $4-10$ 


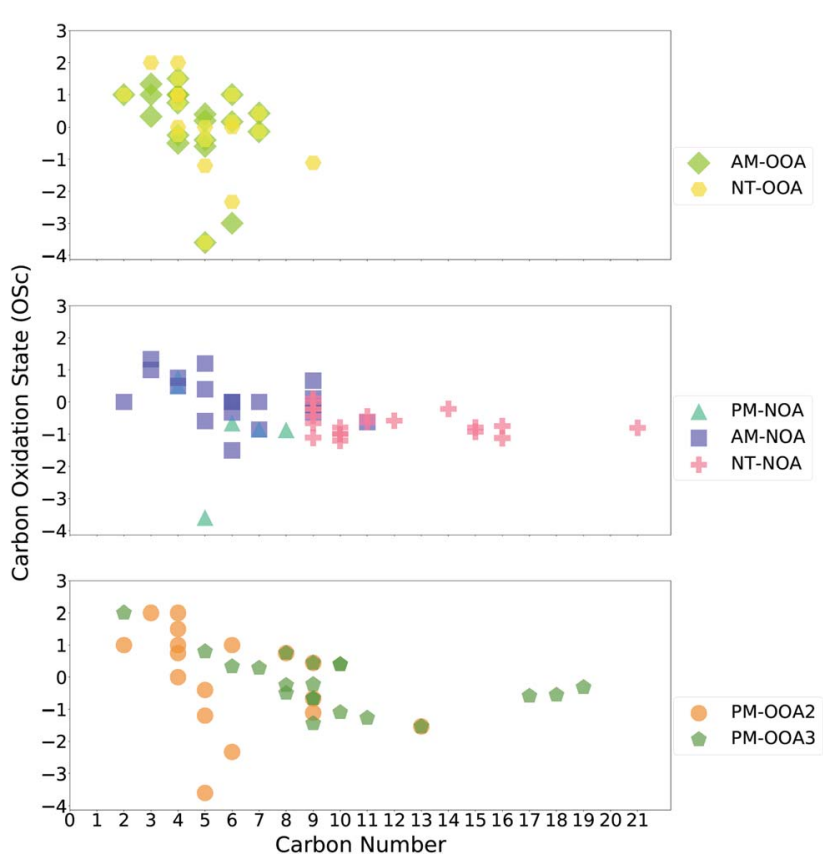

Fig. 4 Oxidation state vs. carbon number plot of top 20 ions most correlated with factors (note: PM-OOA1 shows poor correlation with all ions across the whole time period and thus is not included; its few marker ions during period 2 are discussed in Section 3.4.2).

factor PMF solutions were evaluated, with this factor observed in all solutions. Due to its high contribution to the observed SOA signal in period 2 (27\%), its correlation in this period alone was considered, and three potential marker ions were identified. This approach groups the marker ions whose details and likely origins will be discussed in the next section.

\subsection{Interpretation of factors}

In this section, we bring together the bulk composition presented in Table 1, the comparisons with ring-retaining aromatic SOA products presented in Section 3.2 and the markers identified in Section 3.3, to discuss the likely sources of the factors. The marker ions discussed in this section are presented in Tables S9-S15 $\dagger$ and the most abundant ions for each factor in Tables S1-S8, $\dagger$ with a summary of their potential sources from literature.

3.4.1. Morning factors. AM-OOA consists of small, oxidised ions (C\# 5.45, O\# 4.0, MW 140.58) and has the second smallest contribution from aromatic ringretaining SOA products, suggesting it is highly processed aerosol. Of its marker ions, all were observed in the aromatic SOA experiments, though the majority have other sources including $\alpha$-pinene and isoprene oxidation. The ions potentially related to $\alpha$-pinene are $\mathrm{C}_{4} \mathrm{H}_{4} \mathrm{O}_{4}$ and $\mathrm{C}_{4} \mathrm{H}_{4} \mathrm{O}_{5}$, which were reported to be related to aqueous processing ${ }^{80}$ and $\mathrm{C}_{3} \mathrm{H}_{4} \mathrm{O}_{4}$. Though $\mathrm{C}_{3} \mathrm{H}_{4} \mathrm{O}_{4}$ is widely reported as malonic acid, it was recently suggested on the basis of its measured cluster strength with iodide ${ }^{40}$ that it could be attributed to the modelled 3-oxoperoxypropanoic acid from $\alpha$-pinene oxidation. ${ }^{11}$ The ions potentially related to 
isoprene are $\mathrm{C}_{5} \mathrm{H}_{6} \mathrm{O}_{4},{ }^{81} \mathrm{C}_{5} \mathrm{H}_{10} \mathrm{O}_{4}$ (ref. 45 and 82) and $\mathrm{C}_{4} \mathrm{H}_{8} \mathrm{O}_{3}$, which can correspond to dihydroxycarbonyl compounds from IEPOX oxidation. ${ }^{83}$ Given that IEPOX in Beijing typically peaks in the afternoon under low- $\mathrm{NO}_{x}$ conditions ${ }^{26}$ it is likely in the case of this factor that these ions are associated with the aromatic sources. This is particularly likely for $\mathrm{C}_{4} \mathrm{H}_{8} \mathrm{O}_{3}$ which is one of the most dominant ions observed from oxidation of 1,2,4-trimethyl benzene. ${ }^{1,44}$ Of the remaining ions observed from aromatic oxidation, their potential other sources include oxidation of guaiacol, a biomass burning intermediate, which can form $\mathrm{C}_{4} \mathrm{H}_{6} \mathrm{O}_{5}$ and $\mathrm{C}_{5} \mathrm{H}_{6} \mathrm{O}_{4}$ (ref. 84) alongside aqueous phase reactions of methylglyoxal which can form $\mathrm{C}_{5} \mathrm{H}_{12} \mathrm{~N}_{2} \mathrm{O}_{2}$ and $\mathrm{C}_{6} \mathrm{H}_{12} \mathrm{~N}_{2} \mathrm{O}_{2}{ }^{85}$ Taken together, these observations suggest that this factor is highly influenced by aromatics, and potentially related to aqueous phase processing of biomass burning aerosol.

AM-NOA consists of larger oxidised ions (C\# 7.36, O\# 4.69, MW 177.96), with a contribution of $29 \%$ from $\mathrm{CHON}$ ions and $23 \%$ from HOM ions suggesting less processed aerosol. Aromatic ring-retaining products contribute $19 \%$ to the mass spectrum, the second highest contribution of all factors. Of the 20 marker ions from this factor, 13 were observed in the aromatic SOA experiments, of which 2 have potential contributions from other sources. These are $\mathrm{C}_{3} \mathrm{H}_{4} \mathrm{O}_{4}$ and $\mathrm{C}_{5} \mathrm{H}_{6} \mathrm{O}_{4}$, which were also observed in AM-OOA, and their non-aromatic sources were highlighted as unlikely to be important given the temporal trends of these factors. Of the 7 marker ions not observed in the aromatic SOA experiments, the majority are nitroaromatics which have previously been observed from vehicle emissions ${ }^{\mathbf{8 6}}$ and biomass burning ${ }^{84}$ alongside secondary formation from high- $\mathrm{NO}_{x}$ oxidation of aromatics. ${ }^{43,87-89}$ Specifically, these included $\mathrm{C}_{6} \mathrm{H}_{5} \mathrm{NO}_{4}$ (4-nitrocatechol, Finewax et al., 2018), ${ }^{90} \mathrm{C}_{7} \mathrm{H}_{5} \mathrm{NO}_{5}$ (perbenzoyl nitrate, Busilacchio et al., 2016), ${ }^{91} \mathrm{C}_{7} \mathrm{H}_{7} \mathrm{NO}_{3}$ (methyl nitrophenol, Priestley et al., 2018) ${ }^{92}$ and $\mathrm{C}_{6} \mathrm{H}_{9} \mathrm{NO}_{7}{ }^{43}$

3.4.2. Afternoon factors. PM-NOA is the smallest, both in terms of carbon number and molecular weight, and least oxygenated of the afternoon factors (C\# 6.69, O\# 3.94, MW 158.38) with the highest CHON contribution (36\%) and the highest contribution from aromatic ring-retaining SOA products $(26 \%)$. It has 6 marker ions, none of which were observed in the aromatic SOA experiments. These include the nitroaromatics $\mathrm{C}_{6} \mathrm{H}_{5} \mathrm{NO}_{3}$ and $\mathrm{C}_{7} \mathrm{H}_{7} \mathrm{NO}_{3}$, which can be directly emitted or formed from secondary production as with those in AM-NOA, alongside $\mathrm{C}_{5} \mathrm{H}_{12} \mathrm{~N}_{2} \mathrm{O}_{2}$, an ion associated with the aqueous phase processing of methylglyoxal, ${ }^{85}$ also a marker of AM-OOA. Together these observations indicate that this factor is highly influenced by aromatic oxidation.

PM-OOA1 consists of larger and more oxygenated ions (C\# 7.35, O\# 4.19, MW 171.16) alongside a higher HOM contribution (21\%) and lower CHON contribution (26\%). It also has the lowest contribution from aromatic ring-retaining SOA products (7\%). Its marker ions can only be identified from period 2 and consist of tentatively identified $\mathrm{C}_{14} \mathrm{H}_{20} \mathrm{O}_{7}, \mathrm{C}_{17} \mathrm{H}_{18} \mathrm{O}_{8}$ and $\mathrm{C}_{15} \mathrm{H}_{16} \mathrm{~N}_{2} \mathrm{O}_{5} \cdot \mathrm{C}_{14} \mathrm{H}_{20} \mathrm{O}_{7}$ has been previously attributed to biomass burning, ${ }^{79}$ while $\mathrm{C}_{17} \mathrm{H}_{18} \mathrm{O}_{8}$ was observed during particle nucleation experiments from $\alpha$-pinene ${ }^{93}$ and $\mathrm{C}_{15} \mathrm{H}_{16} \mathrm{~N}_{2} \mathrm{O}_{5}$ has previously been reported as an oligomer formed during aqueous phase methylglyoxal oxidation. ${ }^{94}$ These observations suggest that this factor could have mixed sources, and more information is needed to establish its sources.

PM-OOA2 consists of large oxygenated ions (C\# 7.36, O\# 4.72, MW 178.48) and has the largest contribution (27\%) from HOM ions of the afternoon factors and $13 \%$ contribution from aromatic ring-retaining SOA products. Of the 17 marker 
ions identified for this factor, 14 were observed in the aromatic SOA experiments, 4 of which have potential biogenic sources. Two of these ions are associated with oxidation of isoprene: $\mathrm{C}_{5} \mathrm{H}_{10} \mathrm{O}_{4}$ which is most abundant during low- $\mathrm{NO}_{x}$ conditions ${ }^{45,82}$ and $\mathrm{C}_{4} \mathrm{H}_{8} \mathrm{O}_{4}$ which may correspond to 2-methyl glyceric acid, a major product of isoprene oxidation. ${ }^{95}$ The remaining two consist of $\mathrm{C}_{5} \mathrm{H}_{12} \mathrm{O}_{3}$ which is formed from oxidation of 2-methyl-3-buten-2-ol (MBO) ${ }^{96}$ under low- $\mathrm{NO}_{x}$ conditions and $\mathrm{C}_{4} \mathrm{H}_{4} \mathrm{O}_{5}$ which has been previously attributed to the aqueous phase oxidation of $\alpha$-pinene. ${ }^{80}$ The ions not observed in aromatic SOA include $\mathrm{C}_{9} \mathrm{H}_{12} \mathrm{O}$, likely corresponding to trimethyl phenol and $\mathrm{C}_{13} \mathrm{H}_{26} \mathrm{O}_{3}$, which is potentially attributable to hydroxytridecanoic acid and has previously been reported in a cigarette smoke PMF factor. ${ }^{79}$ Of the aromatic marker ions, two have previously been attributed to 1,3,5-trimethyl benzene oxidation: $\mathrm{C}_{8} \mathrm{H}_{8} \mathrm{O}_{7}$ (ref. 97) and $\mathrm{C}_{9} \mathrm{H}_{16} \mathrm{O}_{5}$, which is a product attributed to a second $\mathrm{OH}$ attack ${ }^{42}$ and another to 1,2,4-trimethyl benzene oxidation $\mathrm{C}_{9} \mathrm{H}_{10} \mathrm{O}_{7}{ }^{44}$ Together these observations suggest that this factor is highly related to low- $\mathrm{NO}_{x}$ oxidation chemistry leading to $\mathrm{HOM}$ formation, with an additional strong influence from isoprene oxidation.

PM-OOA3 shows a similar bulk composition and contribution of aromatic ring-retaining ions to that of PM-OOA2, but a smaller contribution from HOM ions $(20 \%)$. Of its marker ions, 13 are observed in the aromatic SOA experiments, of which 4 have other potential biogenic sources. These include $\mathrm{C}_{8} \mathrm{H}_{12} \mathrm{O}_{5}$ and $\mathrm{C}_{9} \mathrm{H}_{14} \mathrm{O}_{6}$ from limonene, ${ }^{98,99} \mathrm{C}_{10} \mathrm{H}_{12} \mathrm{O}_{8}$ from pinanediol ${ }^{100}$ alongside $\mathrm{C}_{8} \mathrm{H}_{12} \mathrm{O}_{4}$ and $\mathrm{C}_{9} \mathrm{H}_{14} \mathrm{O}_{4}$ from $\alpha$-pinene. ${ }^{101,102}$ Of the marker ions not observed from aromatic oxidation, $\mathrm{C}_{18} \mathrm{H}_{18} \mathrm{O}_{4}, \mathrm{C}_{19} \mathrm{H}_{18} \mathrm{O}_{6}$ were previously associated with degradation of lignin, ${ }^{\mathbf{1 0 3 , 1 0 4}}$ potentially related to barbeque cooking emissions. Taken together these observations suggest that this factor is a mixture of biogenic and anthropogenic SOA, with monoterpene and cooking influences.

3.4.3. Night-time factors. NT-OOA consists of small oxygenated ions (C\# 5.82, O\# 4.52, MW 153) not dissimilar to AM-OOA. It is primarily composed of $\mathrm{CHO}$ ions $(87 \%)$ with a small contribution from HOM $(14 \%)$ and aromatic ringretaining SOA products $(9 \%)$. Of its marker ions, 18 are observed in the aromatic SOA experiments, of which several have potential biogenic sources. These include $\mathrm{C}_{5} \mathrm{H}_{10} \mathrm{O}_{4}, \mathrm{C}_{5} \mathrm{H}_{12} \mathrm{O}_{3}$ and $\mathrm{C}_{5} \mathrm{H}_{8} \mathrm{O}_{4}$ which can be attributed to isoprene oxidation ${ }^{45,82,105,106}$ alongside $\mathrm{C}_{4} \mathrm{H}_{4} \mathrm{O}_{5}, \mathrm{C}_{6} \mathrm{H}_{10} \mathrm{O}_{5}, \mathrm{C}_{7} \mathrm{H}_{9} \mathrm{O}_{4}$ and $\mathrm{C}_{4} \mathrm{H}_{4} \mathrm{O}_{4}$ which could be related to $\alpha$-pinene oxidation..$^{80,102} \mathrm{C}_{6} \mathrm{H}_{10} \mathrm{O}_{5}$ can also be potentially attributed to levoglucosan from biomass burning, while several other ions have potential correspondences with biomass burning, aqueous oxidation or aged aerosol and are similar to those observed in AM-OOA. Taken together, these observations suggest that this factor is a mixed source aged aerosol factor.

NT-NOA is the largest and most oxygenated of all the factors (C\# 8.68, O\# 5.17, MW 205.14) alongside containing the largest contribution from HOM (38\%) and CHON (32\%) ions. It also contains a $16 \%$ contribution from ring-retaining aromatic ions. Of its marker ions, only 2 were observed in aromatic SOA experiments. The remainder include terpene oxidation products such as $\mathrm{C}_{10} \mathrm{H}_{19} \mathrm{NO}_{7}$, $\mathrm{C}_{10} \mathrm{H}_{15} \mathrm{NO}_{6}, \mathrm{C}_{9} \mathrm{H}_{13} \mathrm{NO}_{8}, \mathrm{C}_{9} \mathrm{H}_{13} \mathrm{NO}_{7}, \mathrm{C}_{9} \mathrm{H}_{13} \mathrm{NO}_{9}, \mathrm{C}_{10} \mathrm{H}_{17} \mathrm{NO}_{5}$ and $\mathrm{C}_{9} \mathrm{H}_{15} \mathrm{NO}_{7}$ (ref. 60, 107 and 108) and sesquiterpene oxidation products including $\mathrm{C}_{15} \mathrm{H}_{25} \mathrm{NO}_{8}$, $\mathrm{C}_{15} \mathrm{H}_{25} \mathrm{NO}_{9}$ and $\mathrm{C}_{16} \mathrm{H}_{27} \mathrm{NO}_{7}{ }^{109}$ Together these observations demonstrate that this factor corresponds to a terpene dominated night-time biogenic SOA factor likely associated with $\mathrm{NO}_{3}$ oxidation chemistry. 


\section{Discussion}

\subsection{Regional influences}

Regional transport is an important source of organic aerosol in Beijing and thus here we compare the factors with co-located measurements and air mass fractions derived from HYSPLIT back trajectories ${ }^{110}$ to better understand the regional influences. A map showing the regional boundaries defined in Liu et al. ${ }^{110}$ is included in the ESI (Fig. S9†). Fig. 5 shows that the air masses change frequently in period 1, with a cycling between the northern plateau and the western and eastern north China plain (NCP) regions on timescales of $<1$ day, while periods 2 and 3 have a prolonged contribution from eastern and western NCP air masses, respectively.

Upon inspection of the factors shown in Fig. 5 alongside the air mass fractions, five of the factors show relevant patterns with regional influences and are thus included in Fig. 6 . The factors most likely associated with regional transport include AM-OOA which relates to the NCP (Eastern and Western), PM-OOA1 which relates to air masses from the eastern NCP and NT-OOA which relates to air masses from the western NCP. AM-OOA and NT-OOA are marked by a strong influence from small oxidised ions indicative of highly processed or aged aerosol whose sources are numerous while PM-OOA1 shows few distinctive markers with mixed sources as discussed in Section 3.4. The remaining three factors do not show a distinctive regional influence and are more influenced by biogenic oxidation chemistry, these are shown in Fig. 7 and discussed further in Section 4.3.

Fig. 6 shows six events (A-F) which are defined for illustrative purposes. AMOOA is classified as a morning factor owing to its sharp rises typically occurring during the early morning during events $\mathrm{A}, \mathrm{B}, \mathrm{D}$ and $\mathrm{E}$. Its composition is highly processed and includes ions associated with aqueous phase oxidation of $\alpha$ pinene and methyl glyoxal alongside potential influence from guaiacol oxidation as outlined in Section 3.4.1. Its sharp rise during event B is concurrent with a shift in air mass origin to that from the eastern NCP which is associated with a spike in $\mathrm{SO}_{2}, \mathrm{HCN}$, aromatic hydrocarbons and chloride aerosol indicative of industrial sources. There is also a slight enhancement in sulphate aerosol and $\mathrm{C}_{6} \mathrm{H}_{10} \mathrm{O}_{5}$, typically attributed to levoglucosan, a marker for biomass burning. This spike occurs at around 6 am and thus is likely to be associated with a breakdown and mixing of the residual layer into the boundary layer during the early hours of the day. The behaviour of AM-OOA during period 3 is different owing to a shift in the dominant air mass origin to that from the western NCP. Enhancement of the factor during this period is concurrent with only $\mathrm{C}_{6} \mathrm{H}_{10} \mathrm{O}_{5}$ and aromatics during event $\mathrm{D}$, while during event $\mathrm{E}$ and $\mathrm{F}$ its enhancements are associated with slight increases in aromatics, sulphate and $\mathrm{SO}_{2}$. Events $\mathrm{E}$ and $\mathrm{F}$ in particular show a stronger association of this factor with $\mathrm{C}_{6} \mathrm{H}_{10} \mathrm{O}_{5}$, indicating that the air masses from the western NCP are more related to biomass burning than industrial sources.

NT-OOA appears to represent air masses from the western NCP throughout the measurement period, showing greatest enhancement during event $\mathrm{F}$ in period 3 shown in Fig. 6. The polar plot of NT-OOA (Fig. S12†) shows that this factor is highest at high wind speeds from the west which correspond to the strongest enhancement in $\mathrm{C}_{6} \mathrm{H}_{10} \mathrm{O}_{5}$ during event $\mathrm{F}$. This particular event is not associated with enhancements in any of the other markers and thus suggests it is most likely 


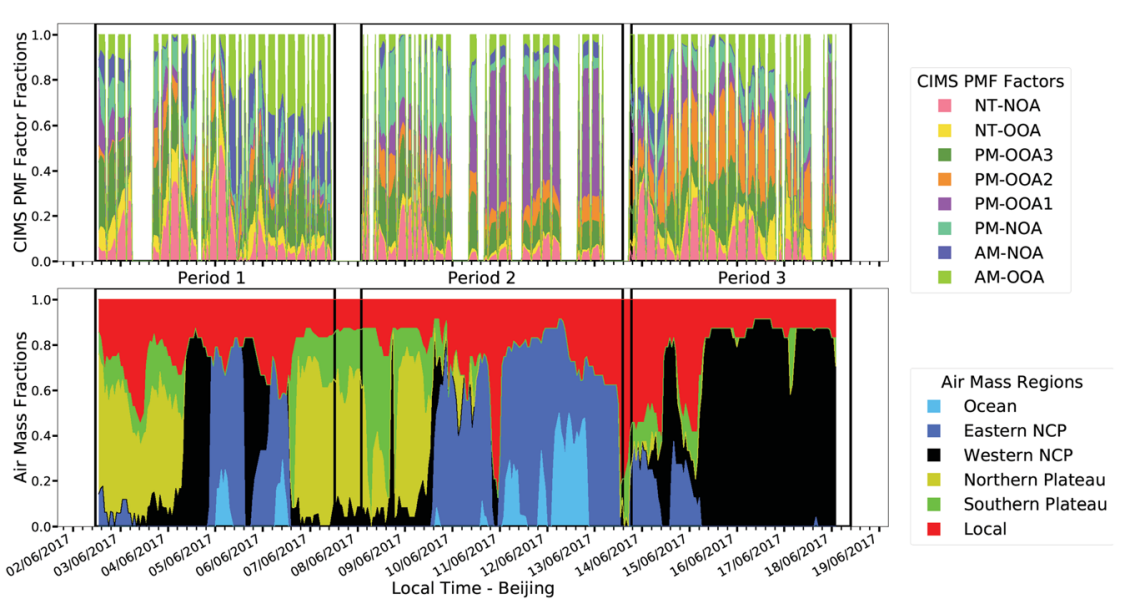

Fig. 5 Comparison of fractional factor contributions with HYSPLIT fractional air mass contributions.

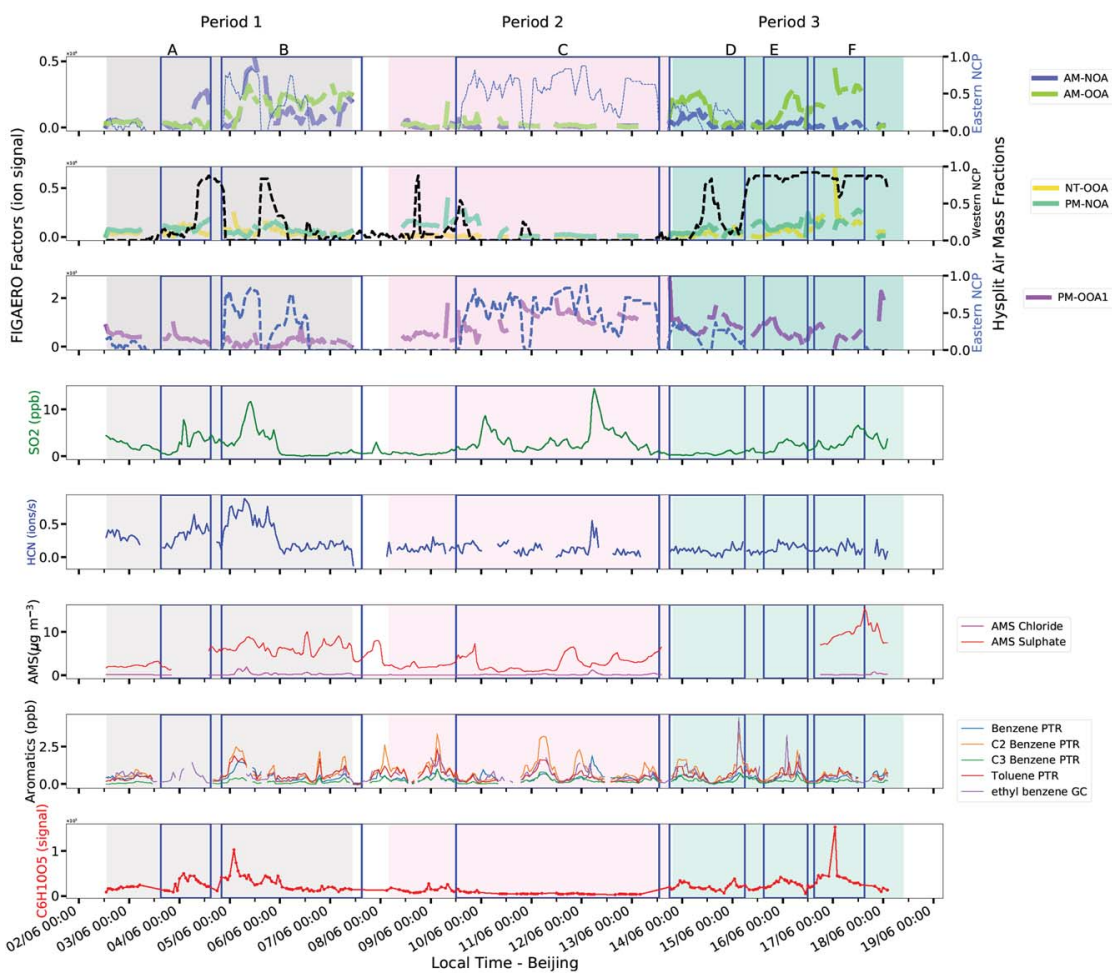

Fig. 6 Comparison of factors with regional influence with external tracers and air mass origins. Events $\mathrm{A}-\mathrm{F}$ are defined in this figure for illustrative purposes.

associated with long range transport of biomass burning aerosol from the western NCP. This is further supported by levoglucosan being both a marker of this factor and its most abundant ion (Tables S2 and S10†). 
PM-OOA1 shows a correspondence with the prolonged air mass contribution from the Eastern NCP during period 2. Its key markers, as discussed in Section 3.4.2, are few and provide limited insight into its sources. During event C in Fig. 6, when this factor is most abundant, the wind direction is strongly from the southeast, where the industrial sources lie and this period contains two spikes in $\mathrm{SO}_{2}$ which suggest an industrial plume. It should be noted that this factor is the most abundant under high- $\mathrm{NO}_{x}$ conditions when aerosol concentrations were also relatively low.

\subsection{Sources and formation of nitro-aromatics}

Nitro-aromatics can be attributed to various sources, including biomass burning ${ }^{111}$ and vehicle emissions, ${ }^{112}$ alongside secondary formation by gas, particle and aqueous phase oxidation processes ${ }^{113,114}$ and are an important contributor to brown carbon in the polluted atmosphere $(\mathrm{BrC}) \cdot{ }^{\mathbf{1 1 5 , 1 1 6}} \mathrm{AM}-\mathrm{NOA}$ and PM-NOA are characterised by nitro-aromatic marker ions and show different temporal trends as well as composition, most likely representing different sources and formation pathways.

AM-NOA, which has the second highest aromatic content of the factors is abundant during the same time periods as the highly-aged AM-OOA (Fig. 6) which suggests that its source may be associated with regional transport and early morning mixing from the residual layer as the boundary layer develops. One potential source of nitro-aromatics in this factor can be related to biomass burning, however its temporal trends are dissimilar to that of $\mathrm{C}_{6} \mathrm{H}_{10} \mathrm{O}_{5}$ (levoglucosan) suggesting that its sources may be different. Its early morning peak suggests a potential influence from traffic, further supported by its polar plot (Fig. S12†) which shows it is elevated at low wind speeds and those from the north/north-east, which may suggest a traffic source from the Jingzang Highway to the east and fourth ring road to the north as has been reported previously for

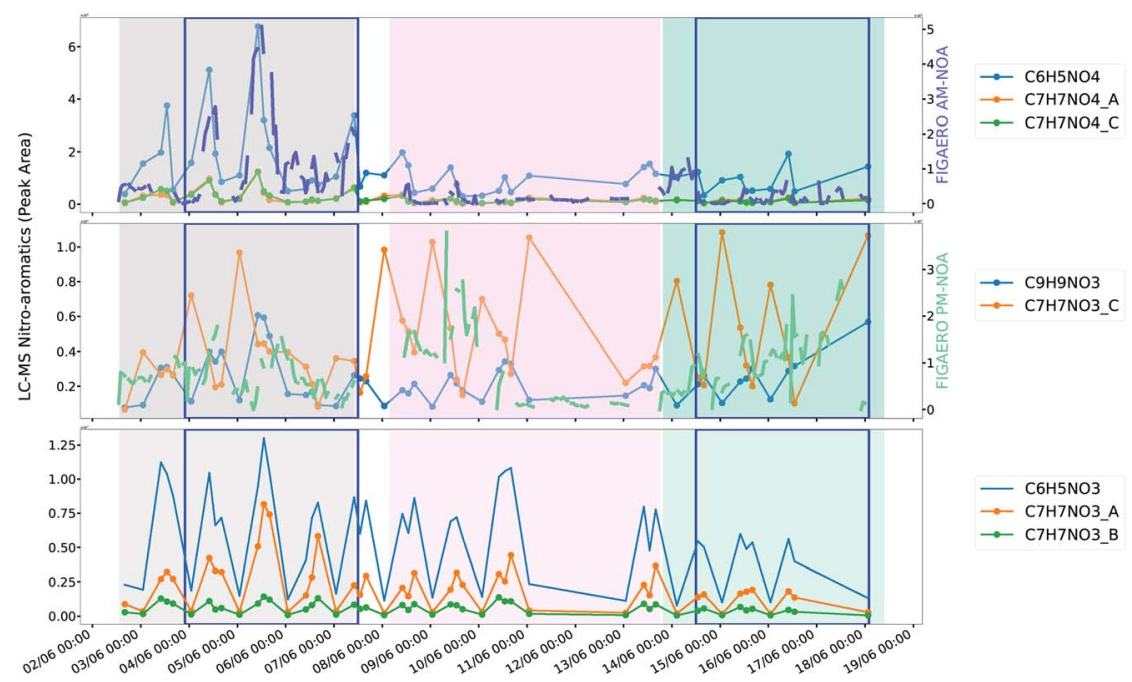

Fig. 7 Comparison of AM-NOA and PM-NOA with nitroaromatic ions measured by UPLCMS. Sample midpoint has been used to plot the offline filter data. 
$\mathrm{NO}_{x}$ emission flux. ${ }^{70}$ This source could be further supported by the increase in HCN, which, though widely thought to be a marker of biomass burning, ${ }^{117}$ has been shown to be an important emission from traffic in urban areas. ${ }^{118}$ However, unlike $\mathrm{NO}_{x}$, which has a reasonably consistent source across the measurement period, ${ }^{70}$ this factor is most abundant during period 1 and appears more episodic in nature than direct source emissions which would typically exhibit more regular diurnal behaviour. In addition, its key nitro-aromatic marker ion is $\mathrm{C}_{6} \mathrm{H}_{5} \mathrm{NO}_{4}$ (4nitrocatechol), which is typically not observed from direct vehicle emissions and is more related to biomass burning or secondary formation..$^{\mathbf{8 8 0}}$ Several other ions measured by UPLC-MS including isomers of $\mathrm{C}_{7} \mathrm{H}_{7} \mathrm{NO}_{4}$ are strongly correlated with AM-NOA as shown in Fig. 7.

$\mathrm{C}_{6} \mathrm{H}_{5} \mathrm{NO}_{4}$ (4-nitrocatechol) is expected to form in the aqueous phase under polluted environmental conditions ${ }^{119}$ and night-time sources such as nitrate radical reactions have been previously suggested to be attributable to their formation. ${ }^{90}$ These factors may suggest, that as with the transported AM-OOA which appears to be introduced into the daytime boundary layer through mixing of the residual layer in the morning, this is related to nitro-aromatics formed in this residual layer overnight. The formation of nitro-aromatics in the residual layer can occur due to a decoupling from the nocturnal boundary layer in which high $\mathrm{O}_{3}$ and low-NO conditions lead to rapid conversion of $\mathrm{NO}_{2}$ to $\mathrm{NO}_{3}$. The potential for aqueous phase pathways to be important are further supported by AM-OOA whose markers include ions associated with aqueous phase oxidation of methyl glyoxal, as discussed in Section 3.3.

The reduction in AM-NOA, which is larger and less oxidised, is concurrent with an increase in AM-OOA (Fig. 6), which is smaller and more highly processed, potentially corresponding to its processing in Beijing while its reduction in period 3 could also be attributed to the elevated temperature which is known to impact upon gas-particle partitioning of nitro-aromatics ${ }^{120}$ alongside gas-phase photolysis ${ }^{121}$ and oxidation due to the higher $\mathrm{OH}$ concentrations measured during period 3. Together, these observations suggest that this factor is strongly influenced by aromatics with a potential influence of transported biomass burning sources or secondary formation in a decoupled residual layer, which are introduced from its mixing as the daytime boundary layer develops.

PM-NOA, which has the highest contribution from ring-retaining aromatic SOA products of all the factors, shows a different temporal profile and a more consistent source throughout the measurement period. In addition, it peaks around peak photochemistry suggesting that it is related to direct emission, potentially from traffic sources or from secondary formation. The markers of this factor include $\mathrm{C}_{6} \mathrm{H}_{5} \mathrm{NO}_{3}$, which can be related to 4-nitrophenol speciated by the UPLC-MS during this measurement period and is typically emitted from vehicle emissions ${ }^{\mathbf{1 1 2 , 1 2 2}}$ and $\mathrm{C}_{7} \mathrm{H}_{7} \mathrm{NO}_{3}$ which is also measured by the UPLC-MS and show more regular diurnal profiles than that of the nitro-aromatic species associated with AM-NOA (Fig. 7).

\subsection{Biogenic influenced chemistry}

While the other factors show a strong relationship from air mass trends, PMOOA2, PM-OOA3 and NT-NOA show a stronger relationship with that of oxidant, radical and VOC concentrations as shown in Fig. 8. As discussed in Section 3.3, these factors are compositionally most influenced by species with 

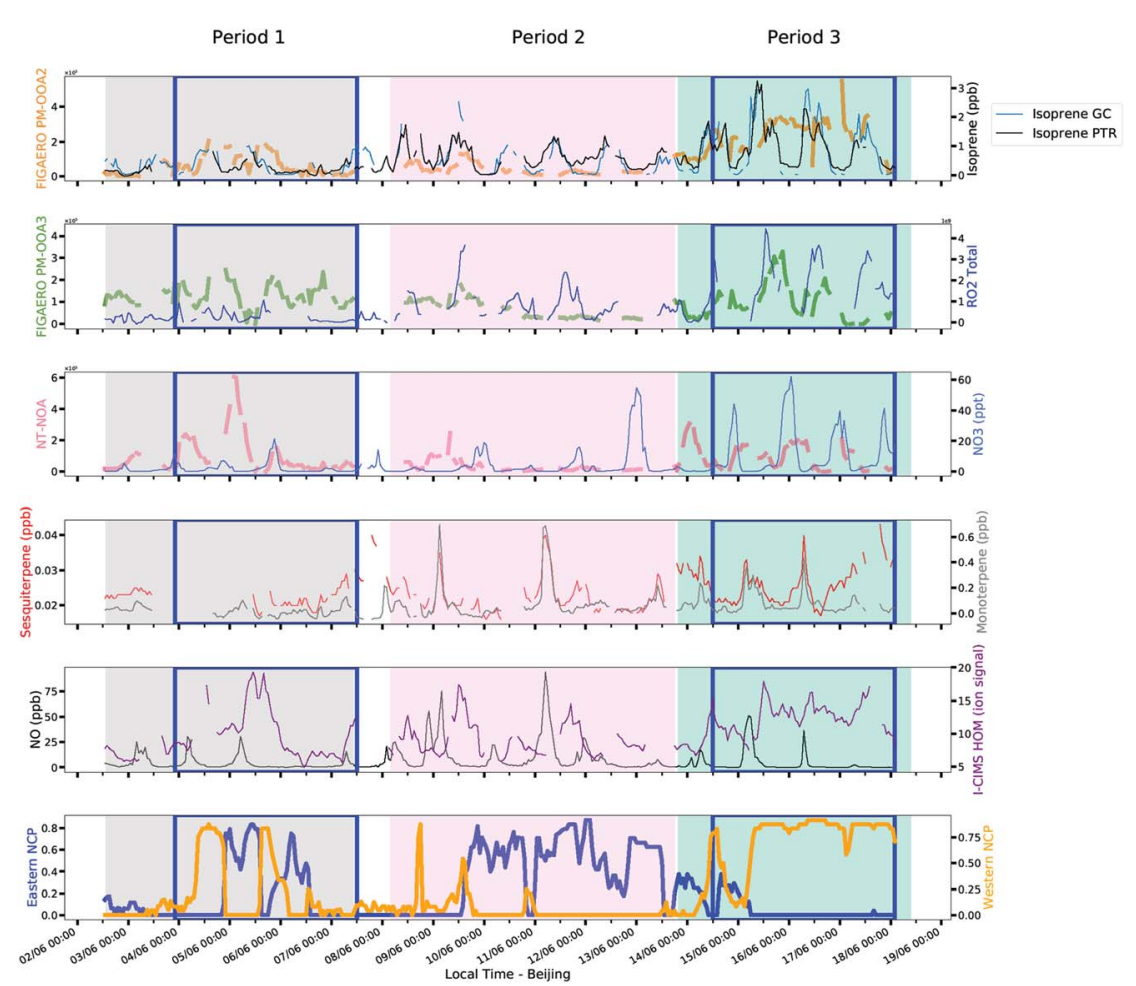

Fig. 8 Comparison of SOA factors with external markers of biogenic sources and chemistry.

biogenic origin, or those formed from low- $\mathrm{NO}_{x}$ oxidation pathways of aromatics such as HOM. These factors are most dynamic and abundant during period 3 , which is least influenced by regional transport.

PM-OOA2 shows a regular diurnal pattern which is consistent throughout the measurement period, with the exception of the end of period 2, when its levels drop down significantly under higher NO conditions shown in Fig. 8. It shows an enhancement in period 3 which corresponds with an increase in measured isoprene and ozone mixing ratios, which along with its composition further suggest this factor is isoprene related. SOA from terpenoid emissions has previously been reported to have a strong exponential relationship with temperature, and is also observed for PM-OOA2 as can be seen in Fig. 9. ${ }^{123-125}$ Though other factors show an elevated contribution under the higher temperatures to a small extent, this is by virtue of them being afternoon factors and the lack of an exponential relationship along with composition less influenced by biogenic SOA products confirms that they are less related to terpenoid emissions. This factor also shows a similar temporal trend to the sum of HOM ions, measured in the gas phase by I-CIMS, consistent with it being the afternoon factor which contains the largest contribution from particle phase HOM ions. This shows that it is not only related to biogenics but more generically to low-NO oxidation pathways, which have recently been identified as an important pathway for isoprene oxidation chemistry in Beijing. ${ }^{24}$ 


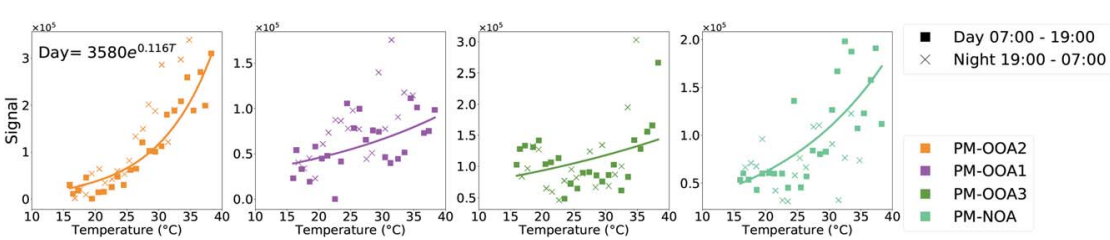

Fig. 9 Temperature dependence of afternoon factors with signal binned hourly by ambient temperature (night is $7 \mathrm{pm}$ to $7 \mathrm{am}$ ).

PM-OOA3 shows little correlation with radicals and oxidants during periods 1 and 2, but a strong correspondence with measured $\mathrm{RO}_{2}$ (described in ESI 1.2.1 $\dagger$ ) and ozone during period 3, suggesting it is related to local formation during this time period. It is likely that during period 1 , the sources of these ions are less related to secondary formation pathways and more related to cooking emissions which contribute to its factor profile and to regional transport given that the measured $\mathrm{RO}_{2}$ radical concentrations are much lower during this time (Fig. 7).

NT-NOA, which is compositionally strongly related to monoterpene and sesquiterpene oxidation and contains the largest contribution from HOM ions, shows a poor correlation with $\mathrm{NO}_{3}$ during periods 1 and 2, again suggesting that during this time period the regional influence to organic aerosol is stronger and the formation cannot be resolved by the PMF and potentially the formation of these products is occurring in the residual layer. In contrast, this factor shows a strong diurnal pattern similar to that of $\mathrm{NO}_{3}$ as well as monoterpene and sesquiterpene concentrations in period 3, as well as a polar plot which shows highest levels under low wind speeds which suggest local formation (Fig. S12†).

\subsection{Comparison with AMS}

A factor analysis of AMS measurements during the same time period identified factors associated with cooking organic aerosol (COA), fossil fuel organic aerosol (FFOA) and three oxidised factors referred to as oxidised primary organic aerosol (OPOA), less-oxidised oxidised organic aerosol (LO-OOA) and more-oxidised oxidised organic aerosol (MO-OOA). Fig. 10 shows the potential correspondences of the FIGAERO factor components with those derived from the AMS, where OPOA, FFOA and COA are related to the factors most influenced by vehicle emissions and regional sources (AM-OOA, NT-OOA, AM-NOA and PM-NOA) and LO-OOA and MOOOA are related to those formed in the afternoon during peak photochemistry and related to biogenic sources (PM-OOA1, PM-OOA2, PM-OOA3 and NT-NOA). It should be noted that the iodide reagent ion scheme would typically not be expected to detect all of the AMS OA, as it is particularly sensitive to multi-functional oxidised species, and thus would be expected to detect the most oxidised portion of what is observed by the AMS. Therefore, the differences in primary-secondary split of the FIGAERO and AMS factors is likely attributable to an increased proportion of less oxidised POA detected by the AMS which the CIMS does not observe, which is likely to be the case during period 2 when the AMS POA fraction is dominant.

Looking at the relative ratios of these factors during different time periods, it is clear that the CIMS factors show additional variation in OA chemical composition that is not captured by the AMS factors. Correlations are observed between 


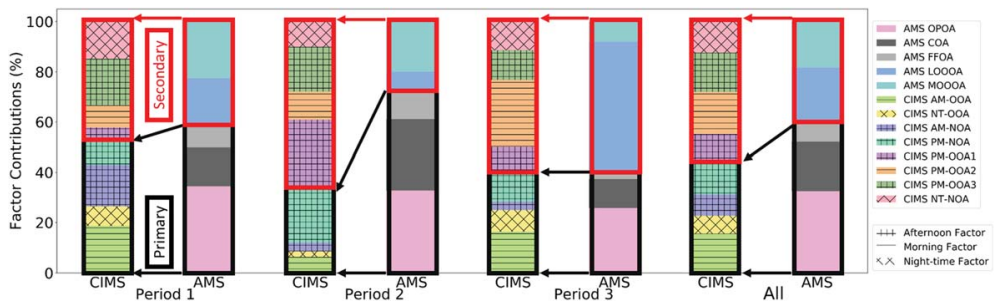

Fig. 10 Comparison in relative contribution of CIMS and AMS PMF factors during different time periods.

increases in AMS factors and CIMS factors between periods suggesting some broad correspondence between them. The most noticeable relationship between these factors is that the AMS shows an enhanced contribution during period 3 from LO-OOA which corresponds to the elevated contribution from PM-OOA2 in the CIMS measurements. This is the factor associated with enhanced SOA formation relating to increased temperature and strong isoprene influence. In contrast, MO-OOA is more abundant during periods 1 and 2, and this likely corresponds best with an increase in relative contributions of PM-OOA3.

\section{Conclusions and implications}

This study presents the first PMF factor analysis of FIGAERO-CIMS measurements from Beijing, identifying eight factors representing anthropogenic and biogenic contributions to OA alongside regional influences.

Regional contributors to $\mathrm{OA}$ in Beijing include air masses from the eastern NCP (AM-OOA and PM-OOA1) and those from the western NCP (NT-OOA) which contribute on average $14 \%, 11 \%$ and $7 \%$, respectively to FIGAERO-CIMS OA factors. Anthropogenic contributions to OA include those from PM-NOA which is most influenced by ring-retaining aromatic SOA products and AM-NOA, which is potentially associated with nocturnal processing of aromatic hydrocarbons in the residual layer, which contribute $13 \%$ and $8 \%$. Biogenic contributions, specifically related to isoprene, monoterpenes and sesquiterpenes exist in mixed factors associated with their chemical oxidation regimes in PM-OOA2, PM-OOA3 and NTNOA, and contribute on average $13 \%, 18 \%$ and $15 \%$ to OA respectively.

Together these observations show that aromatic hydrocarbons are important for SOA in Beijing, both from daytime oxidation and potential regional transport and nocturnal processing. In addition, the oxidation of biogenic emissions is dominated by isoprene during the afternoon, with monoterpene and sesquiterpenes becoming important for $\mathrm{NO}_{3}$ oxidation pathways leading to formation of large oxidised aerosol products overnight. Regional transport is most significant from the eastern NCP, which brings highly polluted air masses which participate in nocturnal processing and are introduced into the urban atmosphere in the morning.

\section{Author contributions}

AM operated the FIGAERO-CIMS, carried out the analysis and wrote the manuscript working closely with $\mathrm{HC}$ and MRC. JA, HC, CP, AM, TB, SDW and AB 
deployed the FIGAERO-CIMS in the field. MRC and HS assisted with the FIGAERO-CIMS and PMF analysis. ES, LW and DH provided the $\mathrm{RO}_{2}$ and $\mathrm{OH}$ data. $\mathrm{JFH}, \mathrm{AE}, \mathrm{SHB}$ and DB provided the LC-MS analysis. JRH provided the GC-FID data. JB provided the SMPS data. BO provided the $\mathrm{NO}_{3}$ data. WJFA, $\mathrm{CNH}$ and XW provided the PTR VOC data. DL carried out the hysplit air mass back trajectory analysis. YS, JZ and WX provided the AMS data and PMF analysis. YS and PF provided the meteorological data. LW, YW and JEK contributed to the aromatic SOA experiments. FS and JL provided the $\mathrm{NO}, \mathrm{NO}_{2}, \mathrm{SO}_{2}$ and $\mathrm{O}_{3}$ measurements. MP, XC, QC, JJ, DW assisted with the interpretation and development of the results in the paper.

\section{Conflicts of interest}

There are no conflicts to declare.

\section{Acknowledgements}

Archit Mehra is fully funded by the Natural Environment Research Council (NERC) and acknowledges his funding through the NERC EAO Doctoral Training Partnership (NE/L002469/1) and CASE partnership support from Aerodyne Research Inc. Funding for this work was provided by the UK Natural Environment Research Council as part of AIRPRO (NE/N00695X/1) and AIRPOLL (NE/N007123/ 1) alongside UK Natural Environment Research Council and UK Medical Research Council funding under the framework of the Newton Innovation Fund (grant NE/ N006976/1).

\section{References}

1 A. Mehra, Y. Wang, J. E. Krechmer, A. Lambe, F. Majluf, M. A. Morris, M. Priestley, T. J. Bannan, D. J. Bryant, K. L. Pereira, J. F. Hamilton, A. R. Rickard, M. J. Newland, H. Stark, P. Croteau, J. T. Jayne, R. Worsnop, M. R. Canagaratna, L. Wang and H. Coe, Atmos. Chem. Phys. Discuss., 2020, 161, 1-28.

2 J. L. Jimenez, M. R. Canagaratna, N. M. Donahue, A. S. H. Prevot, Q. Zhang, J. H. Kroll, P. F. DeCarlo, J. D. Allan, H. Coe, N. L. Ng, A. C. Aiken, K. S. Docherty, I. M. Ulbrich, A. P. Grieshop, A. L. Robinson, J. Duplissy, J. D. Smith, K. R. Wilson, V. A. Lanz, C. Hueglin, Y. L. Sun, J. Tian, A. Laaksonen, T. Raatikainen, J. Rautiainen, P. Vaattovaara, M. Ehn, M. Kulmala, J. M. Tomlinson, D. R. Collins, M. J. Cubison, J. Dunlea, J. A. Huffman, T. B. Onasch, M. R. Alfarra, P. I. Williams, K. Bower, Y. Kondo, J. Schneider, F. Drewnick, S. Borrmann, S. Weimer, K. Demerjian, D. Salcedo, L. Cottrell, R. Griffin, A. Takami, T. Miyoshi,

S. Hatakeyama, A. Shimono, J. Y. Sun, Y. M. Zhang, K. Dzepina, J. R. Kimmel, D. Sueper, J. T. Jayne, S. C. Herndon, A. M. Trimborn, L. R. Williams, E. C. Wood, A. M. Middlebrook, C. E. Kolb, U. Baltensperger and D. R. Worsnop, Science, 2009, 326, 1525-1529.

3 J. Haywood and O. Boucher, Rev. Geophys., 2000, 38, 513-543.

4 U. Pöschl, Angew. Chem., Int. Ed., 2005, 44, 7520-7540. 
5 S. Fuzzi, U. Baltensperger, K. Carslaw, S. Decesari, H. Denier Van Der Gon, M. C. Facchini, D. Fowler, I. Koren, B. Langford, U. Lohmann, E. Nemitz, S. Pandis, I. Riipinen, Y. Rudich, M. Schaap, J. G. Slowik, D. V. Spracklen, E. Vignati, M. Wild, M. Williams and S. Gilardoni, Atmos. Chem. Phys., 2015, 15, 8217-8299.

6 M. Hallquist, J. C. Wenger, U. Baltensperger, Y. Rudich, D. Simpson, M. Claeys, J. Dommen, N. M. Donahue, C. George, A. H. Goldstein, J. F. Hamilton, H. Herrmann, T. Hoffmann, Y. Iinuma, M. Jang, M. E. Jenkin, J. L. Jimenez, A. Kiendler-Scharr, W. Maenhaut, G. Mcfiggans, T. F. Mentel, A. Monod, A. S. H. Prevot, J. Seinfeld, J. D. Surratt, R. Szmigielski and J. Wildt, Atmos. Chem. Phys., 2009, 9, 5155-5236.

7 A. B. Guenther, X. Jiang, C. L. Heald, T. Sakulyanontvittaya, T. Duhl, L. K. Emmons and X. Wang, Geosci. Model Dev., 2012, 5, 1471-1492.

8 J. K. Pearson, Atmos. Environ., 2019, 204, 118-124.

9 K. Sindelarova, C. Granier, I. Bouarar, A. Guenther, S. Tilmes, T. Stavrakou, J.-F. Müller, U. Kuhn, P. Stefani and W. Knorr, Atmos. Chem. Phys., 2014, 14, 9317-9341.

10 G. McFiggans, T. F. Mentel, J. Wildt, I. Pullinen, S. Kang, E. Kleist, S. Schmitt, M. Springer, R. Tillmann, C. Wu, D. Zhao, M. Hallquist, C. Faxon, M. Le Breton, A. M. Hallquist, D. Simpson, R. Bergström, M. E. Jenkin, M. Ehn, J. A. Thornton, M. R. Alfarra, T. J. Bannan, C. J. Percival, M. Priestley, D. Topping and A. Kiendler-Scharr, Nature, 2019, 565, 587-593.

11 S. M. Saunders, M. E. Jenkin, R. G. Derwent and M. J. Pilling, Atmos. Chem. Phys., 2003, 3, 161-180.

12 Z. Chen, D. Chen, M.-P. Kwan, B. Chen, B. Gao, Y. Zhuang, R. Li and B. Xu, Atmos. Chem. Phys., 2019, 19, 13519-13533.

13 Q. Zhang, Y. Zheng, D. Tong, M. Shao, S. Wang, Y. Zhang, X. Xu, J. Wang, H. He, W. Liu, Y. Ding, Y. Lei, J. Li, Z. Wang, X. Zhang, Y. Wang, J. Cheng, Y. Liu, Q. Shi, L. Yan, G. Geng, C. Hong, M. Li, F. Liu, B. Zheng, J. Cao, A. Ding, J. Gao, Q. Fu, J. Huo, B. Liu, Z. Liu, F. Yang, K. He and J. Hao, Proc. Natl. Acad. Sci. U. S. A., 2019, 116, 24463-24469.

14 J. Cheng, J. Su, T. Cui, X. Li, X. Dong, F. Sun, Y. Yang, D. Tong, Y. Zheng, Y. Li, J. Li, Q. Zhang and K. He, Atmos. Chem. Phys., 2019, 19, 6125-6146.

15 B. Zheng, D. Tong, M. Li, F. Liu, C. Hong, G. Geng, H. Li, X. Li, L. Peng, J. Qi, L. Yan, Y. Zhang, H. Zhao, Y. Zheng, K. He and Q. Zhang, Atmos. Chem. Phys., 2018, 18, 14095-14111.

16 A. Guenther, ISRN Atmos. Sci., 2013, 2013, DOI: 10.1155/2013/786290.

17 G. Huang, R. Brook, M. Crippa, G. Janssens-Maenhout, C. Schieberle, C. Dore, D. Guizzardi, M. Muntean, E. Schaaf and R. Friedrich, Atmos. Chem. Phys, 2017, 17, 7683-7701.

18 Y. Sun, Z. Wang, H. Dong, T. Yang, J. Li, X. Pan, P. Chen and J. T. Jayne, Atmos. Environ., 2012, 51, 250-259.

19 Q. Li, G. Su, C. Li, P. Liu, X. Zhao, C. Zhang, X. Sun, Y. Mu, M. Wu, Q. Wang and B. Sun, Sci. Total Environ., 2020, 720, 137536.

20 Z. An, R.-J. Huang, R. Zhang, X. Tie, G. Li, J. Cao, W. Zhou, Z. Shi, Y. Han, Z. Gu and Y. Ji, Proc. Natl. Acad. Sci. U. S. A., 2019, 116, 8657-8666.

21 Y. Sun, W. Xu, Q. Zhang, Q. Jiang, F. Canonaco, A. S. H. Prévôt, P. Fu, J. Li, J. Jayne, D. R. Worsnop and Z. Wang, Atmos. Chem. Phys., 2018, 18, 8469-8489. 
22 J. Li, Z. Han, J. Li, R. Liu, Y. Wu, L. Liang and R. Zhang, Sci. Total Environ., 2020, 703, 134937.

23 Y. Wang, M. Hu, S. Guo, Y. Wang, J. Zheng, Y. Yang, W. Zhu, R. Tang, X. Li, Y. Liu, M. Le Breton, Z. Du, D. Shang, Y. Wu, Z. Wu, Y. Song, S. Lou, M. Hallquist and J. Yu, Atmos. Chem. Phys., 2018, 18, 10693-10713.

24 M. J. Newland, D. J. Bryant, R. E. Dunmore, T. J. Bannan, W. J. F. Acton, B. Langford, J. R. Hopkins, F. A. Squires, W. Dixon, W. S. Drysdale, P. D. Ivatt, M. J. Evans, P. M. Edwards, L. K. Whalley, D. E. Heard, E. J. Slater, R. Woodward-Massey, C. Ye, A. Mehra, S. D. Worrall, A. Bacak, H. Coe, C. J. Percival, C. N. Hewitt, J. D. Lee, T. Cui, J. D. Surratt, X. Wang, A. C. Lewis, A. R. Rickard and J. F. Hamilton, Atmos. Chem. Phys. Discuss., DOI: $10.5194 /$ acp-2020-35.

25 J. Li, G. Wang, C. Wu, C. Cao, Y. Ren, J. Wang, J. Li, J. Cao, L. Zeng and T. Zhu, Sci. Rep., 2018, 8, 535.

26 D. Bryant, W. Dixon, J. Hopkins, R. Dunmore, K. Pereira, M. Shaw, F. Squires, T. Bannan, A. Mehra, S. Worrall, A. Bacak, H. Coe, C. Percival, L. Whalley, D. Heard, E. Slater, B. Ouyang, T. Cui, J. Surratt, D. Liu, Z. Shi, R. Harrison, Y. Sun, W. Xu, A. Lewis, J. Lee, A. Rickard and J. Hamilton, Atmos. Chem. Phys. Discuss., 2019, 1-30.

27 R. Tang, Z. Z. Wu, X. Li, Y. Wang, D. Shang, Y. Xiao, M. Li, L. Zeng, Z. Z. Wu, M. Hallquist, M. Hu and S. Guo, Atmos. Chem. Phys., 2018, 18, 4055-4068.

28 Y. Gao, H. Wang, X. Zhang, S. Jing, Y. Peng, L. Qiao, M. Zhou, D. D. Huang, Q. Wang, X. Li, L. Li, J. Feng, Y. Ma and Y. Li, Environ. Sci. Technol., 2019, 53, 8664-8671.

29 F. Yang, K. Kawamura, J. Chen, K. Ho, S. Lee, Y. Gao, L. Cui, T. Wang and P. Fu, Atmos. Environ., 2016, 124, 166-175.

30 Q. Zhang, J. L. Jimenez, M. R. Canagaratna, I. M. Ulbrich, N. L. Ng, D. R. Worsnop, Y. Sun, Q. Zhang, Y. Sun, J. L. Jimenez, I. M. Ulbrich, M. R. Canagaratna, N. L. Ng and D. R. Worsnop, Anal. Bioanal. Chem., 2011, 401, 3045-3067.

31 J. Li, Z. Liu, W. Gao, G. Tang, B. Hu, Z. Ma and Y. Wang, Atmos. Environ., 2020, 220, 117070.

32 W. Hu, M. Hu, W. Hu, J. L. Jimenez, B. Yuan, W. Chen, M. Wang, Y. Wu, C. Chen, Z. Wang, J. Peng, L. Zeng and M. Shao, J. Geophys. Res.: Atmos., 2016, 121, 1955-1977.

33 T. J. Bannan, A. Bacak, J. B. A. Muller, A. M. Booth, B. Jones, M. Le Breton, K. E. Leather, M. Ghalaieny, P. Xiao, D. E. Shallcross and C. J. Percival, Atmos. Environ., 2014, 83, 301-310.

34 L. G. Huey, Mass Spectrom. Rev., 2007, 26, 166-184.

35 P. Veres, J. M. Roberts, C. Warneke, D. Welsh-Bon, M. Zahniser, S. Herndon, R. Fall and J. De Gouw, Int. J. Mass Spectrom., 2008, 274, 48-55.

36 R. Woodward-Massey, Y. M. Taha, S. G. Moussa and H. D. Osthoff, Atmos. Environ., 2014, 98, 693-703.

37 B. H. Lee, F. D. Lopez-Hilfiker, E. L. D’ambro, P. Zhou, M. Boy, T. Petäjä, L. Hao, A. Virtanen and J. A. Thornton, Atmos. Chem. Phys., 2018, 18, 11547-11562.

38 F. D. Lopez-Hilfiker, C. Mohr, E. L. D’ambro, A. Lutz, T. P. Riedel, C. J. Gaston, S. Iyer, Z. Zhang, A. Gold, J. D. Surratt, B. H. Lee, T. Kurten, W. W. Hu, 
J. Jimenez, M. Hallquist and J. A. Thornton, Environ. Sci. Technol., 2016, 50, 2200-2209.

39 G. Isaacman-VanWertz, P. Massoli, R. E. O’Brien, J. B. Nowak, M. R. Canagaratna, J. T. Jayne, D. R. Worsnop, L. Su, D. A. Knopf, P. K. Misztal, C. Arata, A. H. Goldstein and J. H. Kroll, Faraday Discuss., 2017, 200, 579-598.

40 G. Isaacman-VanWertz, P. Massoli, R. O’Brien, C. Lim, J. P. Franklin, J. A. Moss, J. F. Hunter, J. B. Nowak, M. R. Canagaratna, P. K. Misztal, C. Arata, J. R. Roscioli, S. T. Herndon, T. B. Onasch, A. T. Lambe, J. T. Jayne, L. Su, D. A. Knopf, A. H. Goldstein, D. R. Worsnop and J. H. Kroll, Nat. Chem., 2018, 10, 462-468.

41 M. Riva, P. Rantala, J. E. Krechmer, O. Peräkylä, Y. Zhang, L. Heikkinen, O. Garmash, C. Yan, M. Kulmala, D. Worsnop and M. Ehn, Atmos. Meas. Tech., 2019, 12, 2403-2421.

42 U. Molteni, F. Bianchi, F. Klein, I. El Haddad, C. Frege, M. J. Rossi, J. Dommen and U. Baltensperger, Atmos. Chem. Phys., 2018, 18, 1909-1921.

43 E. Tsiligiannis, J. Hammes, C. M. Salvador, T. F. Mentel and M. Hallquist, Atmos. Chem. Phys., 2019, 19, 15073-15086.

44 A. Zaytsev, A. R. Koss, M. Breitenlechner, J. E. Krechmer, K. J. Nihill, C. Y. Lim, J. C. Rowe, J. L. Cox, J. Moss, J. R. Roscioli, M. R. Canagaratna, D. R. Worsnop, J. H. Kroll and F. N. Keutsch, Atmos. Chem. Phys., 2019, 19, 15117-15129.

45 E. L. D'ambro, B. H. Lee, J. Liu, J. E. Shilling, C. J. Gaston, F. D. Lopez-Hilfiker, S. Schobesberger, R. A. Zaveri, C. Mohr, A. Lutz, Z. Zhang, A. Gold, J. D. Surratt, J. C. Rivera-Rios, F. N. Keutsch and J. A. Thornton, Atmos. Chem. Phys., 2017, 17, 159-174.

46 D. Aljawhary, A. K. Y. Lee and J. P. D. Abbatt, Atmos. Meas. Tech., 2013, 6, 3211-3224.

47 O. Garmash, M. P. Rissanen, I. Pullinen, S. Schmitt, O. Kausiala, R. Tillmann, C. Percival, T. J. Bannan, M. Priestley, Å. M. Hallquist, E. Kleist, A. KiendlerScharr, M. Hallquist, T. Berndt, G. McFiggans, J. Wildt, T. F. Mentel and M. Ehn, Atmos. Chem. Phys., 2020, 20, 515-537.

48 F. Bianchi, T. Kurtén, M. Riva, C. Mohr, M. P. Rissanen, P. Roldin, T. Berndt, J. D. Crounse, P. O. Wennberg, T. F. Mentel, J. Wildt, H. Junninen, T. Jokinen, M. Kulmala, D. R. Worsnop, J. A. Thornton, N. Donahue, H. G. Kjaergaard and M. Ehn, Chem. Rev., 2019, 119, 3472-3509.

49 W. Huang, H. Saathoff, A. Pajunoja, X. Shen, K.-H. Naumann, R. Wagner, A. Virtanen, T. Leisner and C. Mohr, Atmos. Chem. Phys., 2018, 18, 2883-2898. 50 C. Mohr, F. D. Lopez-Hilfiker, T. Yli-Juuti, A. Heitto, A. Lutz, M. Hallquist, E. L. D’Ambro, M. P. Rissanen, L. Hao, S. Schobesberger, M. Kulmala, R. L. Mauldin, U. Makkonen, M. Sipilä, T. Petäjä and J. A. Thornton, Geophys. Res. Lett., 2017, 44, 2958-2966.

51 L. Yao, O. Garmash, F. Bianchi, J. Zheng, C. Yan, J. Kontkanen, H. Junninen, S. B. Mazon, M. Ehn, P. Paasonen, M. Sipilä, M. Wang, X. Wang, S. Xiao, H. Chen, Y. Lu, B. Zhang, D. Wang, Q. Fu, F. Geng, L. Li, H. Wang, L. Qiao, X. Yang, J. Chen, V. M. Kerminen, T. Petäjä, D. R. Worsnop, M. Kulmala and L. Wang, Science, 2018, 361, 278-281.

52 C. Yan, W. Nie, M. Äijälä, M. P. Rissanen, M. R. Canagaratna, P. Massoli, H. Junninen, T. Jokinen, N. Sarnela, S. Häme, S. Schobesberger, 
F. Canonaco, A. S. H. Prevot, T. Petäjä, M. Kulmala, M. Sipilä, D. R. Worsnop and M. Ehn, Atmos. Chem. Phys., 2016, 16, 12715-12731.

53 Y. Zhang, O. Peräkylä, C. Yan, L. Heikkinen, M. Äijälä, K. R. Daellenbach, Q. Zha, M. Riva, O. Garmash, H. Junninen, P. Paatero, D. Worsnop and M. Ehn, Atmos. Chem. Phys., 2020, 20, 5945-5961.

54 J. Brean, R. M. Harrison, Z. Shi, D. C. S. Beddows, W. J. F. Acton, C. N. Hewitt, F. A. Squires and J. Lee, Atmos. Chem. Phys., 2019, 19, 14933-14947.

55 C. Mohr, J. A. Thornton, A. Heitto, F. D. Lopez-Hilfiker, A. Lutz, I. Riipinen, J. Hong, N. M. Donahue, M. Hallquist, T. Petäjä, M. Kulmala and T. YliJuuti, Nat. Commun., 2019, 10, 4442.

56 V. Pospisilova, F. D. Lopez-Hilfiker, D. M. Bell, I. El Haddad, C. Mohr, W. Huang, L. Heikkinen, M. Xiao, J. Dommen, A. S. H. Prevot, U. Baltensperger and J. G. Slowik, Sci. Adv., 2020, 6(11), eaax8922.

57 F. D. Lopez-Hilfiker, C. Mohr, M. Ehn, F. Rubach, E. Kleist, J. Wildt, T. F. Mentel, A. Lutz, M. Hallquist, D. Worsnop and J. A. Thornton, Atmos. Meas. Tech., 2014, 7, 983-1001.

58 B. H. Lee, F. D. Lopez-Hilfiker, C. Mohr, T. Kurtén, D. R. Worsnop, J. A. Thornton, T. Kurte, D. R. Worsnop, J. A. Thornton, T. Kurtén, D. R. Worsnop and J. A. Thornton, Environ. Sci. Technol., 2014, 48, 6309-6317. 59 M. Le Breton, Y. Wang, Å. M. Hallquist, R. K. Pathak, J. Zheng, Y. Yang, D. Shang, M. Glasius, T. J. Bannan, Q. Liu, C. K. Chan, C. J. Percival, W. Zhu, S. Lou, D. Topping, Y. Wang, J. Yu, K. Lu, S. Guo, M. Hu and M. Hallquist, Atmos. Chem. Phys., 2018, 18, 10355-10371.

60 P. Massoli, H. Stark, M. R. Canagaratna, J. E. Krechmer, L. Xu, N. L. Ng, R. L. Mauldin, C. Yan, J. Kimmel, P. K. Misztal, J. L. Jimenez, J. T. Jayne and D. R. Worsnop, ACS Earth Space Chem., 2018, 2, 653-672.

61 Y. Chen, M. Takeuchi, T. Nah, L. Xu, M. R. Canagaratna, H. Stark, K. Baumann, F. Canonaco, A. S. H. Prévôt, L. G. Huey, R. J. Weber and N. L. Ng, Atmos. Chem. Phys. Discuss., 2020, 20, 8421-8440.

62 I. M. Ulbrich, M. R. Canagaratna, Q. Zhang, D. R. Worsnop and J. L. Jimenez, Atmos. Chem. Phys., 2009, 9, 2891-2918.

63 Z. Shi, T. Vu, S. Kotthaus, R. M. Harrison, S. Grimmond, S. Yue, T. Zhu, J. Lee, Y. Han, M. Demuzere, R. E. Dunmore, L. Ren, D. Liu, Y. Wang, O. Wild, J. Allan, W. J. Acton, J. Barlow, B. Barratt, D. Beddows, W. J. Bloss, G. Calzolai, D. Carruthers, D. C. Carslaw, Q. Chan, L. Chatzidiakou, Y. Chen, L. Crilley, H. Coe, T. Dai, R. Doherty, F. Duan, P. Fu, B. Ge, M. Ge, D. Guan, J. F. Hamilton, K. He, M. Heal, D. Heard, C. N. Hewitt, M. Hollaway, M. Hu, D. Ji, X. Jiang, R. Jones, M. Kalberer, F. J. Kelly, L. Kramer, B. Langford, C. Lin, A. C. Lewis, J. Li, W. Li, H. Liu, J. Liu, M. Loh, K. Lu, F. Lucarelli, G. Mann, G. McFiggans, M. R. Miller, G. Mills, P. Monk, E. Nemitz, F. O'Connor, B. Ouyang, P. I. Palmer, C. Percival, O. Popoola, C. Reeves, A. R. Rickard, L. Shao, G. Shi, D. Spracklen, D. Stevenson, Y. Sun, Z. Sun, S. Tao, S. Tong, Q. Wang, W. Wang, X. Wang, X. Wang, Z. Wang, L. Wei, L. Whalley, X. Wu, Z. Wu, P. Xie, F. Yang, Q. Zhang, Y. Zhang, Y. Zhang and M. Zheng, Atmos. Chem. Phys., 2019, 19, 7519-7546.

64 J. Lelieveld, S. Gromov, A. Pozzer and D. Taraborrelli, Atmos. Chem. Phys., 2016, 16, 12477-12493. 
65 J. H. Kroll, N. M. Donahue, J. L. Jimenez, S. H. Kessler, M. R. Canagaratna, K. R. Wilson, K. E. Altieri, L. R. Mazzoleni, A. S. Wozniak, H. Bluhm, E. R. Mysak, J. D. Smith, C. E. Kolb and D. R. Worsnop, Nat. Chem., 2011, 3, 133-139.

66 C. Xavier, A. Rusanen, P. Zhou, C. Dean, L. Pichelstorfer, P. Roldin and M. Boy, Atmos. Chem. Phys., 2019, 19, 13741-13758.

67 N. L. Ng, J. H. Kroll, A. W. H. Chan, P. S. Chhabra, R. C. Flagan and J. H. Seinfeld, Atmos. Chem. Phys., 2007, 7, 3909-3922.

68 J. Odum, T. Hoffmann, F. Bowman, D. Collins, R. C. Flagan and J. H. Seinfeld, Environ. Sci. Technol., 1996, 30, 2580-2585.

69 W. Wu, B. Zhao, S. Wang and J. Hao, J. Environ. Sci., 2017, 53, 224-237.

70 F. A. Squires, E. Nemitz, B. Langford, O. Wild, W. S. Drysdale, W. J. F. Acton, P. Fu, C. B. Sue Grimmond, J. F. Hamilton, C. N. Hewitt, M. Hollaway, S. Kotthaus, J. Lee, S. Metzger, N. Pingintha-Durden, M. Shaw, A. R. Vaughan, X. Wang, R. Wu, Q. Zhang and Y. Zhang, Atmos. Chem. Phys. Discuss., 2020, 20, 8737-8761.

71 J. Sun, F. Wu, B. Hu, G. Tang, J. Zhang and Y. Wang, Atmos. Environ., 2016, 141, 560-570.

72 W. Yang, Y. Zhang, X. Wang, S. Li, M. Zhu, Q. Yu, G. Li, Z. Huang, H. Zhang, Z. Wu, W. Song, J. Tan and M. Shao, Atmos. Chem. Phys., 2018, 18, 1266312682.

73 Y. Sun, Z. Wang, O. Wild, W. Xu, C. Chen, P. Fu, W. Du, L. Zhou, Q. Zhang, T. Han, Q. Wang, X. Pan, H. Zheng, J. Li, X. Guo, J. Liu and D. R. Worsnop, Sci. Rep., 2016, 6, 20668.

74 N. M. Donahue, K. E. Huff Hartz, B. Chuong, A. A. Presto, C. O. Stanier, T. Rosenhørn, A. L. Robinson and S. N. Pandis, Faraday Discuss., 2005, 130, 295-309.

75 C. L. Faiola, A. Buchholz, E. Kari, P. Yli-Pirilä, J. K. Holopainen, M. Kivimäenpää, P. Miettinen, D. R. Worsnop, K. E. J. Lehtinen, A. B. Guenther and A. Virtanen, Sci. Rep., 2018, 8, 3053.

76 E. Ahlberg, J. Falk, A. Eriksson, T. Holst, W. H. Brune, A. Kristensson, P. Roldin and B. Svenningsson, Atmos. Environ., 2017, 161, 210-220.

77 T. U. Ansari, O. Wild, J. Li, T. Yang, W. Xu, Y. Sun and Z. Wang, Atmos. Chem. Phys., 2019, 19, 8651-8668.

78 N. M. Donahue, K. M. Henry, T. F. Mentel, A. Kiendler-Scharr, C. Spindler, B. Bohn, T. Brauers, H. P. Dorn, H. Fuchs, R. Tillmann, A. Wahner, H. Saathoff, K.-H. Naumann, O. Möhler, T. Leisner, L. Müller, M.-C. Reinnig, T. Hoffmann, K. Salo, M. Hallquist, M. Frosch, M. Bilde, T. Tritscher, P. Barmet, A. P. Praplan, P. F. Decarlo, J. Dommen, A. S. H. Prévôt and U. Baltensperger, Proc. Natl. Acad. Sci. U. S. A., 2012, 109, 13503-13508.

79 L. Qi, M. Chen, G. Stefenelli, V. Pospisilova, Y. Tong, A. Bertrand, C. Hueglin, X. Ge, U. Baltensperger, A. S. H. Prévôt and J. G. Slowik, Atmos. Chem. Phys., 2019, 19, 8037-8062.

80 M. Takeuchi and N. L. Ng, Atmos. Chem. Phys., 2019, 19, 12749-12766.

81 C. H. Clark, S. Nakao, A. Asa-Awuku, K. Sato and D. R. Cocker, Aerosol Sci. Technol., 2013, 47, 1374-1382.

82 T. Berndt, H. Herrmann, M. Sipilä and M. Kulmala, J. Phys. Chem. A, 2016, 120(51), 10150-10159. 
83 K. H. Bates, T. B. Nguyen, A. P. Teng, J. D. Crounse, H. G. Kjaergaard, B. M. Stoltz, J. H. Seinfeld and P. O. Wennberg, J. Phys. Chem. A, 2016, 120, 106-117.

84 L. D. Yee, K. E. Kautzman, C. L. Loza, K. A. Schilling, M. M. Coggon, P. S. Chhabra, M. N. Chan, A. W. H. Chan, S. P. Hersey, J. D. Crounse, P. O. Wennberg, R. C. Flagan and J. H. Seinfeld, Atmos. Chem. Phys., 2013, 13, 8019-8043.

85 D. O. De Haan, E. Tapavicza, M. Riva, T. Cui, J. D. Surratt, A. C. Smith, M.-C. Jordan, S. Nilakantan, M. Almodovar, T. N. Stewart, A. de Loera, A. C. De Haan, M. Cazaunau, A. Gratien, E. Pangui and O. Doussin, Environ. Sci. Technol., 2018, 52, 4061-4071.

86 M. A. J. Harrison, S. Barra, D. Borghesi, D. Vione, C. Arsene and R. Iulian Olariu, Atmos. Environ., 2005, 39, 231-248.

87 L. Wang, X. Wang, R. Gu, H. Wang, L. Yao, W. Liang, F. Zhu, W. Wang, L. Xue, L. Yang, K. Lu, J. Chen, T. Wang, Y. Zhang and W. Wang, Atmos. Chem. Phys., 2018, 18, 4349-4359.

88 M. Li, X. Wang, C. Lu, R. Li, J. Zhang, S. Dong, L. Yang, L. Xue, J. Chen and W. Wang, Sci. Total Environ., 2020, 714, 136760.

89 K. L. Pereira, J. F. Hamilton, A. R. Rickard, W. J. Bloss, M. S. Alam, M. Camredon, M. W. Ward, K. P. Wyche, A. Mun, T. Vera, N. Va, E. Borra and M. Ro, Environ. Sci. Technol., 2015, 49, 13168-13178.

90 Z. Finewax, J. A. De Gouw and P. J. Ziemann, Environ. Sci. Technol., 2018, 52, 1981-1989.

91 M. Busilacchio, P. Di Carlo, E. Aruffo, F. Biancofiore, C. D. Salisburgo, F. Giammaria, S. Bauguitte, J. Lee, S. Moller, J. Hopkins, S. Punjabi, S. Andrews, A. C. Lewis, M. Parrington, P. I. Palmer, E. Hyer and G. M. Wolfe, Atmos. Chem. Phys., 2016, 16, 3485-3497.

92 M. Priestley, M. Le Breton, T. J. Bannan, K. E. Leather, A. Bacak, E. ReyesVillegas, F. De Vocht, B. M. A. Shallcross, T. Brazier, M. Anwar Khan, J. Allan, D. E. Shallcross, H. Coe and C. J. Percival, J. Geophys. Res.: Atmos., 2018, 123, 7687-7704.

93 C. Zuth, PhD thesis, Johannes Gutenberg-Universitat Mainz, 2018.

94 P. K. Aiona, H. J. Lee, R. Leslie, P. Lin, A. Laskin, J. Laskin and S. A. Nizkorodov, ACS Earth Space Chem., 2017, 1, 522-532.

95 C. Giorio, A. Monod, L. Brégonzio-Rozier, H. L. Dewitt, M. Cazaunau, B. Temime-Roussel, A. Gratien, V. Michoud, E. Pangui, S. Ravier, A. T. Zielinski, A. Tapparo, R. Vermeylen, M. Claeys, D. Voisin, M. Kalberer and J.-F. Doussin, J. Phys. Chem. A, 2017, 121, 7641-7654.

96 H. Zhang, Z. Zhang, T. Cui, Y.-H. Lin, N. A. Bhathela, J. Ortega, D. R. Worton, A. H. Goldstein, A. Guenther, J. L. Jimenez, A. Gold and J. D. Surratt, Environ. Sci. Technol. Lett., 2014, 1, 242-247.

97 A. P. Praplan, K. Hegyi-Gaeggeler, P. Barmet, L. Pfaffenberger, J. Dommen and U. Baltensperger, Atmos. Chem. Phys., 2014, 14, 8665-8677.

98 J. F. Hamilton, M. R. Alfarra, K. P. Wyche, M. W. Ward, A. C. Lewis, G. B. Mcfiggans, N. Good, P. S. Monks, T. Carr, I. R. White and R. M. Purvis, Atmos. Chem. Phys., 2011, 11, 5917-5929.

99 S. Kundu, R. Fisseha, A. L. Putman, T. A. Rahn and L. R. Mazzoleni, Atmos. Chem. Phys., 2012, 12, 5523-5536. 
100 S. Schobesberger, H. Junninen, F. Bianchi, G. Lönn, M. Ehn, K. Lehtipalo, J. Dommen, S. Ehrhart, I. K. Ortega, A. Franchin, T. Nieminen, F. Riccobono, M. Hutterli, J. Duplissy, J. Almeida, A. Amorim, M. Breitenlechner, A. J. Downard, E. M. Dunne, R. C. Flagan, M. Kajos, H. Keskinen, J. Kirkby, A. Kupc, A. Kürten, T. Kurtén, A. Laaksonen, S. Mathot, A. Onnela, A. P. Praplan, L. Rondo, F. D. Santos, S. Schallhart, R. Schnitzhofer, M. Sipilä, A. Tomé, G. Tsagkogeorgas, H. Vehkamäki, D. Wimmer, U. Baltensperger, K. S. Carslaw, J. Curtius, A. Hansel, T. Petäjä, M. Kulmala, N. M. Donahue and D. R. Worsnop, Proc. Natl. Acad. Sci. U. S. A., 2013, 110, 17223-17228.

101 X. Zhang, R. C. Mcvay, D. D. Huang, N. F. Dalleska, B. Aumont, R. C. Flagan and J. H. Seinfeld, Proc. Natl. Acad. Sci. U. S. A., 2015, 112, 14168-14173.

102 H. Zhang, L. D. Yee, B. H. Lee, M. P. Curtis, D. R. Worton, G. IsaacmanVanWertz, J. H. Offenberg, M. Lewandowski, T. E. Kleindienst, M. R. Beaver, A. L. Holder, W. A. Lonneman, K. S. Docherty, M. Jaoui, H. O. T. Pye, W. Hu, D. A. Day, P. Campuzano-Jost, J. L. Jimenez, H. Guo, R. J. Weber, J. De Gouw, A. R. Koss, E. S. Edgerton, W. Brune, C. Mohr, F. D. Lopez-Hilfiker, A. Lutz, N. M. Kreisberg, S. R. Spielman, S. V. Hering, K. R. Wilson, J. A. Thornton and A. H. Goldstein, Proc. Natl. Acad. Sci. U. S. A., 2018, 115, 2038-2043.

103 E. A. Dalluge, PhD thesis, Iowa State University, 2013.

104 L. Khachatryan, M. Barekati-Goudarzi, D. Kekejian, G. Aguilar, R. Asatryan, G. G. Stanley and D. Boldor, Energy Fuels, 2018, 32, 12597-12606.

105 B. Wang and A. Laskin, J. Geophys. Res.: Atmos., 2014, 119, 3335-3351.

106 W. W. Hu, P. Campuzano-Jost, B. B. Palm, D. A. Day, A. M. Ortega, P. L. Hayes, J. E. Krechmer, Q. Chen, M. Kuwata, Y. J. Liu, S. S. de Sá, K. McKinney, S. T. Martin, M. Hu, S. H. Budisulistiorini, M. Riva, J. D. Surratt, J. M. St Clair, G. Isaacman-Van Wertz, L. D. Yee, A. H. Goldstein, S. Carbone, J. Brito, P. Artaxo, J. A. de Gouw, A. Koss, A. Wisthaler, T. Mikoviny, T. Karl, L. Kaser, W. Jud, A. Hansel, K. S. Docherty, M. L. Alexander, N. H. Robinson, H. Coe, J. D. Allan, M. R. Canagaratna, F. Paulot and J. L. Jimenez, Atmos. Chem. Phys., 2015, 15, 11807-11833.

107 B. H. Lee, C. Mohr, F. D. Lopez-Hilfiker, A. Lutz, M. Hallquist, L. Lee, P. Romer, R. C. Cohen, S. Iyer, T. Kurten, W. Hu, D. A. Day, P. CampuzanoJost, J. L. Jimenez, L. Xu, N. L. Ng, H. Guo, R. J. Weber, R. J. Wild, S. S. Brown, A. Koss, J. de Gouw, K. Olson, A. H. Goldstein, R. Seco, S. Kim, K. McAvey, P. B. Shepson, T. Starn, K. Baumann, E. S. Edgerton, J. Liu, J. E. Shilling, D. O. Miller, W. Brune, S. Schobesberger, E. L. D'Ambro and J. A. Thornton, Proc. Natl. Acad. Sci. U. S. A., 2016, 113, 1516-1521.

108 C. M. Boyd, J. Sanchez, L. Xu, A. J. Eugene, T. Nah, W. Y. Tuet, M. I. Guzman and N. L. Ng, Atmos. Chem. Phys., 2015, 15, 7497-7522.

109 M. N. Chan, J. D. Surratt, A. W. H. Chan, K. Schilling, J. H. Offenberg, M. Lewandowski, E. O. Edney, T. E. Kleindienst, M. Jaoui, E. S. Edgerton, R. L. Tanner, S. L. Shaw, M. Zheng, E. M. Knipping and J. H. Seinfeld, Atmos. Chem. Phys., 2011, 11, 1735-1751.

110 D. Liu, R. Joshi, J. Wang, C. Yu, J. D. Allan, H. Coe, M. J. Flynn, C. Xie, J. Lee, F. Squires, S. Kotthaus, S. Grimmond, X. Ge, Y. Sun and P. Fu, Atmos. Chem. Phys., 2019, 19, 6749-6769. 
111 A. Laskin, J. S. Smith and J. Laskin, Environ. Sci. Technol., 2009, 43, 37643771.

112 S. Inomata, A. Fushimi, K. Sato, Y. Fujitani and H. Yamada, Atmos. Environ., 2015, 110, 93-102.

113 Y. Wang, M. Hu, Y. Wang, J. Zheng, D. Shang, Y. Yang, Y. Liu, X. Li, R. Tang, W. Zhu, Z. Du, Y. Wu, S. Guo, Z. Wu, S. Lou, M. Hallquist, J. Zhen Yu and M. Hu, Atmos. Chem. Phys., 2019, 19, 7649-7665.

114 K. Vidović, D. Lašič Jurković, M. Šala, A. Kroflič and I. Grgić, Environ. Sci. Technol., 2018, 52, 9722-9730.

115 C. Wu, G. Wang, J. Li, J. Li, C. Cao, S. Ge, Y. Xie, J. Chen, X. Li, G. Xue, X. Wang, Z. Zhao and F. Cao, Atmos. Chem. Phys., 2020, 20, 2017-2030.

116 S. H. Budisulistiorini, M. Riva, M. Williams, J. Chen, M. Itoh, J. D. Surratt and M. Kuwata, Environ. Sci. Technol., 2017, 51, 4415-4423.

117 M. Le Breton, A. Bacak, J. B. A. Muller, S. J. O’Shea, P. Xiao, M. N. R. Ashfold, M. C. Cooke, R. Batt, D. E. Shallcross, D. E. Oram, G. Forster, S. J. B. Bauguitte and C. J. Percival, Atmos. Chem. Phys., 2013, 13, 9217-9232.

118 S. G. Moussa, A. Leithead, S.-M. Li, T. W. Chan, J. J. B. Wentzell, C. Stroud, J. Zhang, P. Lee, G. Lu, J. R. Brook, K. Hayden, J. Narayan and J. Liggio, Atmos. Environ., 2016, 131, 185-195.

119 E. H. Hoffmann, A. Tilgner, R. Wolke, O. Bö, A. Walter and H. Herrmann, Phys. Chem. Chem. Phys., 2018, 20, 10960-10977.

120 B. Yuan, J. Liggio, J. Wentzell, S.-M. Li, H. Stark, J. M. Roberts, J. Gilman, B. Lerner, C. Warneke, R. Li, A. Leithead, H. D. Osthoff, R. Wild, S. S. Brown and J. A. De Gouw, Atmos. Chem. Phys., 2016, 16, 2139-2153.

121 I. Bejan, I. Barnes, R. Olariu, S. Zhou, P. Wiesen and T. Benter, Phys. Chem. Chem. Phys., 2007, 9, 5686-5692.

122 C. Lu, X. Wang, S. Dong, J. Zhang, J. Li, Y. Zhao, Y. Liang, L. Xue, H. Xie, Q. Zhang and W. Wang, Environ. Res., 2019, 179, 108709.

123 W. R. Leaitch, A. M. Macdonald, P. C. Brickell, J. Liggio, S. J. Sjostedt, A. Vlasenko, J. W. Bottenheim, L. Huang, S. M. Li, P. S. K. Liu, D. ToomSauntry, K. A. Hayden, S. Sharma, N. C. Shantz, H. A. Wiebe, W. Zhang, J. P. D. Abbatt, J. G. Slowik, R. Y. W. Chang, L. M. Russell, R. E. Schwartz, S. Takahama, J. T. Jayne and N. L. Ng, Atmos. Environ., 2011, 45, 6696-6704.

124 A. Vlachou, K. R. Daellenbach, C. Bozzetti, B. Chazeau, G. A. Salazar, S. Szidat, J.-L. Jaffrezo, C. Hueglin, U. Baltensperger, I. El Haddad and A. S. H. Prévôt, Atmos. Chem. Phys., 2018, 18, 6187-6206.

125 G. Stefenelli, V. Pospisilova, F. D. Lopez-Hilfiker, K. R. Daellenbach, C. Hüglin, Y. Tong, U. Baltensperger, A. S. H. Prévôt and J. G. Slowik, Atmos. Chem. Phys., 2019, 19, 14825-14848. 